San Jose State University

SJSU ScholarWorks

Master's Theses

Master's Theses and Graduate Research

Spring 2017

\title{
Remains of the 19th Century: Deep Storage of Hydraulic Mining Sediment Along the Lower Yuba River, California
}

Tyler Kou Nakamura

San Jose State University

Follow this and additional works at: https://scholarworks.sjsu.edu/etd_theses

\section{Recommended Citation}

Nakamura, Tyler Kou, "Remains of the 19th Century: Deep Storage of Hydraulic Mining Sediment Along the Lower Yuba River, California" (2017). Master's Theses. 4815.

DOI: https://doi.org/10.31979/etd.uvgs-92x2

https://scholarworks.sjsu.edu/etd_theses/4815

This Thesis is brought to you for free and open access by the Master's Theses and Graduate Research at SJSU ScholarWorks. It has been accepted for inclusion in Master's Theses by an authorized administrator of SJSU ScholarWorks. For more information, please contact scholarworks@sjsu.edu. 
REMAINS OF THE $19^{\text {TH }}$ CENTURY: DEEP STORAGE OF HYDRAULIC MINING SEDIMENT ALONG THE LOWER YUBA RIVER, CALIFORNIA

\author{
A Thesis \\ Presented to \\ The Faculty of the Department of Geology \\ San José State University \\ In Partial Fulfillment \\ of the Requirement for the Degree \\ Master of Science
}

By

Tyler Nakamura

May 2017 
(c) 2017

Tyler Nakamura

ALL RIGHTS RESERVED 
The Designated Thesis Committee Approves the Thesis Titled

REMAINS OF THE $19^{\text {TH }}$ CENTURY: DEEP STORAGE OF HYDRAULIC MINING SEDIMENT ALONG THE LOWER YUBA RIVER, CALIFORNIA

by

Tyler Nakamura

APPROVED FOR THE DEPARTMENT OF GEOLOGY

SAN JOSÉ STATE UNIVERSITY

MAY 2017

Emmanuel Gabet, Ph.D. Department of Geology, San José State University

Michael Singer, Ph.D. University of California, Santa Barbara Earth Research Institute

David Andersen, Ph.D. Department of Geology San José State University 


\section{ABSTRACT}

\section{REMAINS OF THE $19^{\text {TH }}$ CENTURY: DEEP STORAGE OF HYDRAULIC MINING SEDIMENT ALONG THE LOWER YUBA RIVER, CALIFORNIA}

\section{by Tyler Nakamura}

Since the onset of hydraulic mining in the Sierra Nevada in 1852, the environmental damage caused by displacement and storage of hydraulic mining sediment (HMS) has been a significant problem in downstream environments. Large volumes of mercury-laden HMS from the Yuba River watershed were deposited within the river corridor between the present site of Englebright Dam and the city of Marysville, CA, creating the anthropogenic Yuba Fan. However, there are outstanding uncertainties about how much HMS is still contained within this fan. To quantify the deep storage of HMS, I collected sediment from borings and outcrops along the lower Yuba Fan and analyzed mercury concentrations at multiple depths. The mercury concentrations served as chemostratigraphic markers, which I used to find the stratigraphic contact depths between the HMS and underlying pre-mining deposits. I found in these hydraulic mining sediments mercury concentrations of order $10^{-1} \mathrm{ppm}$ orders of magnitude, which are ten-fold higher than the pre-mining deposits. My analysis of the lower Yuba Fan's volume suggests that over the span of 147 years approximately $8.99 \times 10^{7} \mathrm{~m}^{3}$ of HMS have been deposited within the study area between 1852 and 1999. Moreover, I estimate that $4.24 \times 10^{3} \mathrm{~kg}$ of mercury are presently stored along the floodplains of the Yuba River where the mercury may continue to enter the food web and have detrimental effects on the local ecosystems. 


\section{ACKNOWLEDGEMENTS}

I am grateful to all of those with whom I had the pleasure to work with during this project. I would like to thank my advisor Dr. Emmanuel Gabet, who has been an excellent mentor and tremendously supportive of my career goals. Thanks to Dr. Michael Singer for his terrific guidance and sharing his scientifically creative ideas. Much appreciation goes to Dr. David Andersen for his valuable input and assistance in the sediment laboratory. This project would not have been possible without the outstanding laboratory work performed by Dr. Mark MarvinDiPasquale, Le Kieu, and the rest of the scientists at the USGS Mercury Lab in Menlo Park, CA. Thanks to Zach Jaco and Thomas Mykytyn for the tremendous help they provided in the field and laboratory. Thank you to Dr. Hilde Schwartz, Dr. Noah Finnegan, and Dr. Slawek Tulaczyk of the University of California Santa Cruz for sparking my interest in geology during my undergraduate years. Special thanks are due to Anthony Guerriero and the rest of my friends at the USGS Santa Cruz field office (Bruce, Cameron, Matt, Louie, Sierra, Steve, and Trevor) for being great coworkers and ensuring that I finish my degree. I would like to thank my parents, grandparents and the rest of my family, whose support and guidance are with me in whatever I pursue. Thank you to my girlfriend Tracy for always being a joyful person. 


\section{TABLE OF CONTENTS}

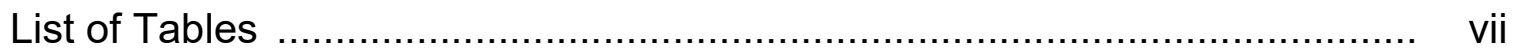

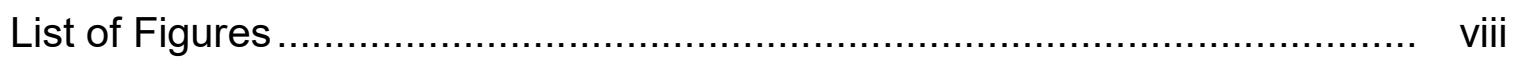

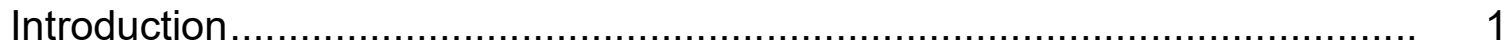

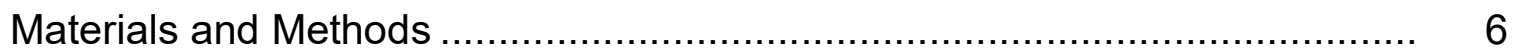

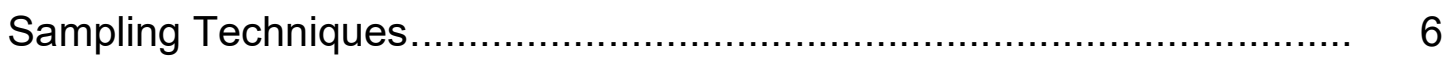

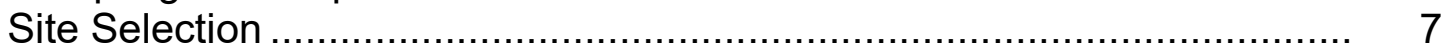

Grain Size Distribution Analysis ……......................................... 8

Mercury Concentration Analysis.................................................. 9

Chemostratigraphy Analysis...................................................... 9

Geographic Information Systems Analysis ........................................ 10

Mercury Volume and Mass Calculations ............................................. 11

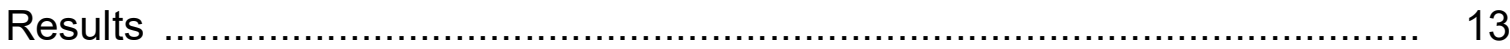

Sampling Location Information ................................................... 13

Grain Size Distributions ......................................................... 13

Mercury Concentrations ........................................................ 14

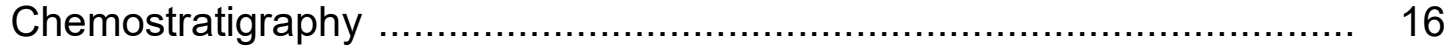

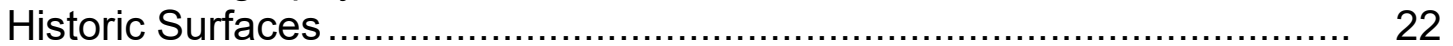

Amount of Erosion and Deposition .................................................... 27

Total Volume and Mass of Mercury in the Lower Yuba Fan..................... 29

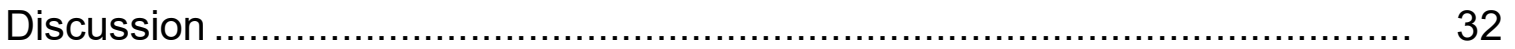

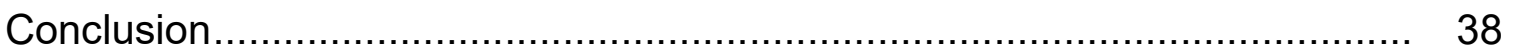

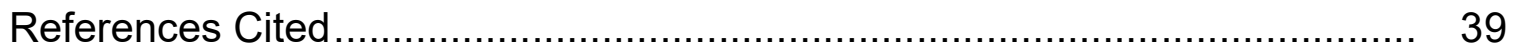

Appendix A. Sampling Location Information ........................................... 43

Appendix B. Geographic Information Systems Spatial Data........................ 44 


\section{LIST OF TABLES}

Table 1. Boring chemostratigraphy analysis results ................................ 18

Table 2. Outcrop chemostratigraphy analysis results .............................. 20

Table 3. Sediment and color classification statistics for hydraulic mining and pre-mining sediment ..................................................... 21

Table 4. Summary of the cut-and-fill operation results .............................. 28 


\section{LIST OF FIGURES}

Figure 1. Lower Yuba River between Marysville, CA, and the Englebright Dam.

Figure 2. G. K. Gilbert's 1917 map of the extent of the hydraulic mining sediment fan deposits along the Yuba River

Figure 3. Lower Yuba Fan study area ……….................................. 5

Figure 4. Sampling locations at Blue Point Mine and Rose Bar ................ 8

Figure 5. Shepard classification ternary diagrams................................. 14

Figure 6. Boring and outcrop sample concentrations in parts per million .... 15

Figure 7. Blue Point Mine and Rose Bar sample mercury concentrations in parts per million ............................................................. 16

Figure 8. Digital elevation models (DEM) representing the surface of the lower Yuba Fan at four points in time.

Figure 9. Maps showing the change in elevation in meters for the following time intervals: 1852 to 1911,1911 to 1952,1952 to 1999, and 1852 to 1999

Figure 10. Cross Section A to A' ........................................................... 26

Figure 11. Cross Section B to B' ................................................... 26

Figure 12. Cross Section $C$ to $C^{\prime}$.......................................................... 27

Figure 13. Maps showing areas of deposition and erosion during specified time intervals 


\section{INTRODUCTION}

Large-scale hydraulic mining operations in the Sierra Nevada began in 1852 and lasted until the Sawyer Decision halted mining in 1884 (Alpers and Hunerlach, 2000). The hydraulic mines in the northern Sierra Nevada during this time used high pressure water cannons to erode Tertiary auriferous gravel deposits. The slurry produced from the hydraulic mining was diverted into a system of sluice-boxes where a large portion of the gold was removed from the gravels via gravity separation. Mercury was used to further recover gold from the mining ore by adding it to the sluice-boxes so that it would alloy with the gold, forming an amalgam. The amalgam was recovered and then roasted to isolate the gold (Averill, 1946). Approximately $1.2 \times 10^{7} \mathrm{~kg}$ of mercury were used by the mines in the Sierra Nevada during the mid to late 1800s (Alpers and Hunerlach, 2000).

Mercury was lost to the environment during the process of recovering gold from the Tertiary gravels within the sluice-boxes. The amount of mercury lost from the sluice-boxes depended on the quantity of water used, sluice slope, sluice length, and the presence of leaks (Bowie, 1893). Averill (1946) investigated hydraulic mines operating in the 1930s, which had again been legalized in 1893, and found that approximately 10 - 30\% of mercury was lost from the sluices to the environment per operating season. The majority of the mines in the Sierra Nevada washed the hydraulic mining sediment (HMS) and waste left over from the amalgamation process into nearby creeks and 
rivers (Hunerlach et al., 1999), where it was susceptible to downstream transport (Bowie, 1893).

Geomorphic changes linked to HMS downstream of the mines have been a significant issue since the onset of hydraulic mining (Gilbert, 1917; James, 1989; James, 1991; James et al., 2009; Ghoshal et al., 2010; Kilham et al., 2012; Singer et al., 2013; Higson and Singer, 2015). The large amount of sedimentation caused flooding, altered the course of the rivers, and disrupted agricultural operations (Gilbert, 1917; James, 2005). In 1884, due to damage associated with the mines, Judge Lorenzo Sawyer issued an injunction against the mining operations to discontinue hydraulic mining operations (James, 2005). The Caminetti Act of 1893 legalized hydraulic mining with the provision that mining tailings would be prevented from reaching adjacent streams (James, 2005). Under the Caminetti Act, the California Debris Commission (CDC) inspected sediment detention structures and issued licenses for specific volumes of sediment releases. Between 1893 and 1950, mercury continued to be used to extract gold from the mining sediment. The mercury-rich sediment was stored onsite and the geomorphic effects were less significant compared to the HMS produced from 1853 to 1884 .

The Yuba River basin (Fig. 1) had more HMS deposited within it than any other area in the United States (Lindgren, 1911). Gilbert (1917) estimated that $5.23 \times 10^{8} \mathrm{~m}^{3}$ of HMS were produced within the mines along the Yuba River between 1849 and 1908. Gilbert's field work revealed that a large fan deposit of 
HMS had accumulated from the confluence between the Yuba River and Deer Creek, located directly upstream of the Narrows, to the mouth of the Yuba River at Marysville (Fig. 2). Gilbert (1917) estimated that the volume of the fan deposit was approximately $2.52 \times 10^{8} \mathrm{~m}^{3}$.

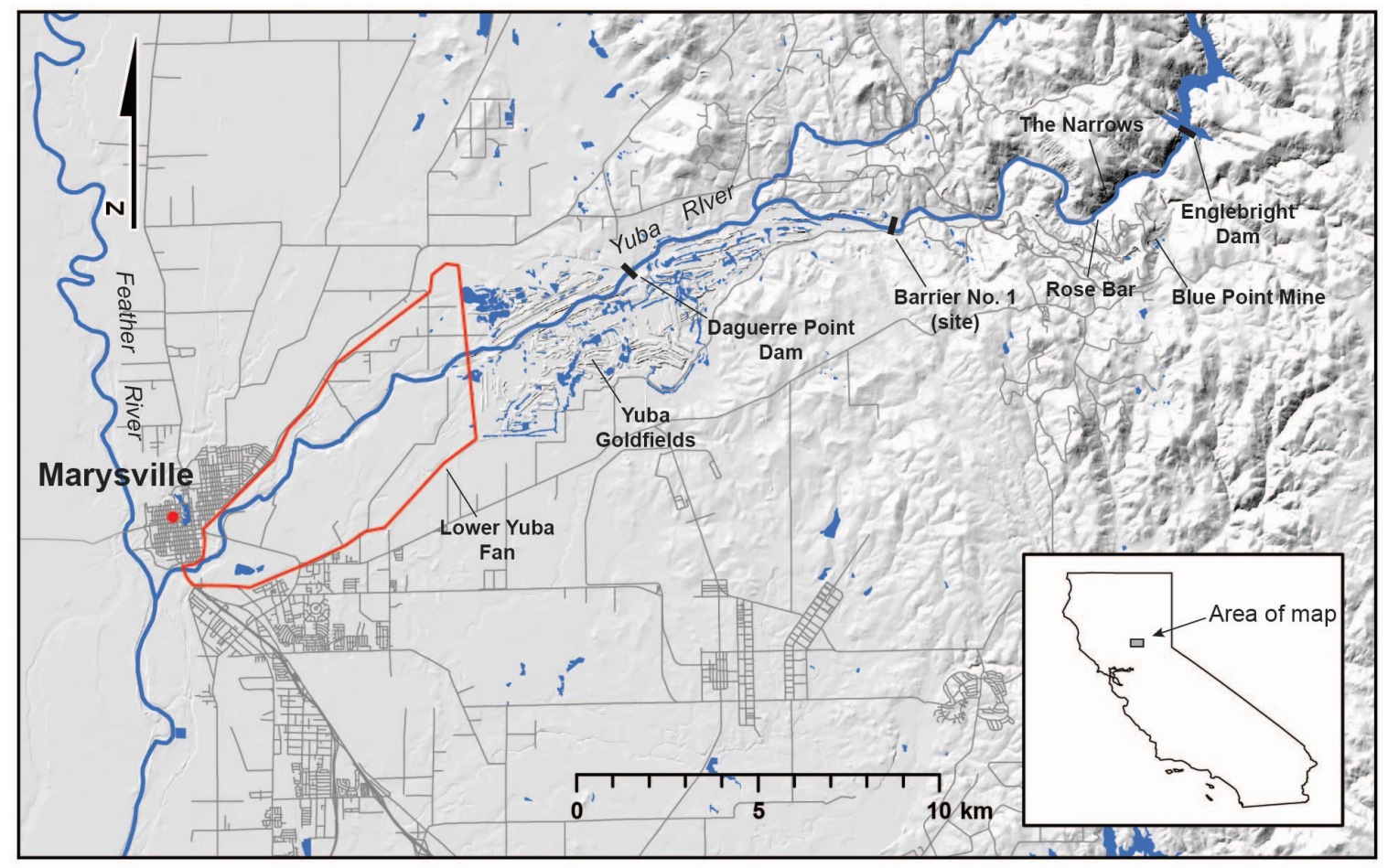

Figure 1. Lower Yuba River between Marysville, CA, and the Englebright Dam. The red polygon near Marysville, CA, outlines the lower Yuba Fan.

Base: Digital elevation model from the U.S. Geological Survey (2013).

The mercury-laden HMS introduced to the Yuba River and other watersheds throughout the Sierra Nevada and Central Valley is a significant concern due to the potential harm that the mercury can cause to the ecosystem and to humans. The inorganic mercury within the HMS can be converted to neurotoxic monomethylmercury by microbes living in the water (Gilmour et al., 2013). 


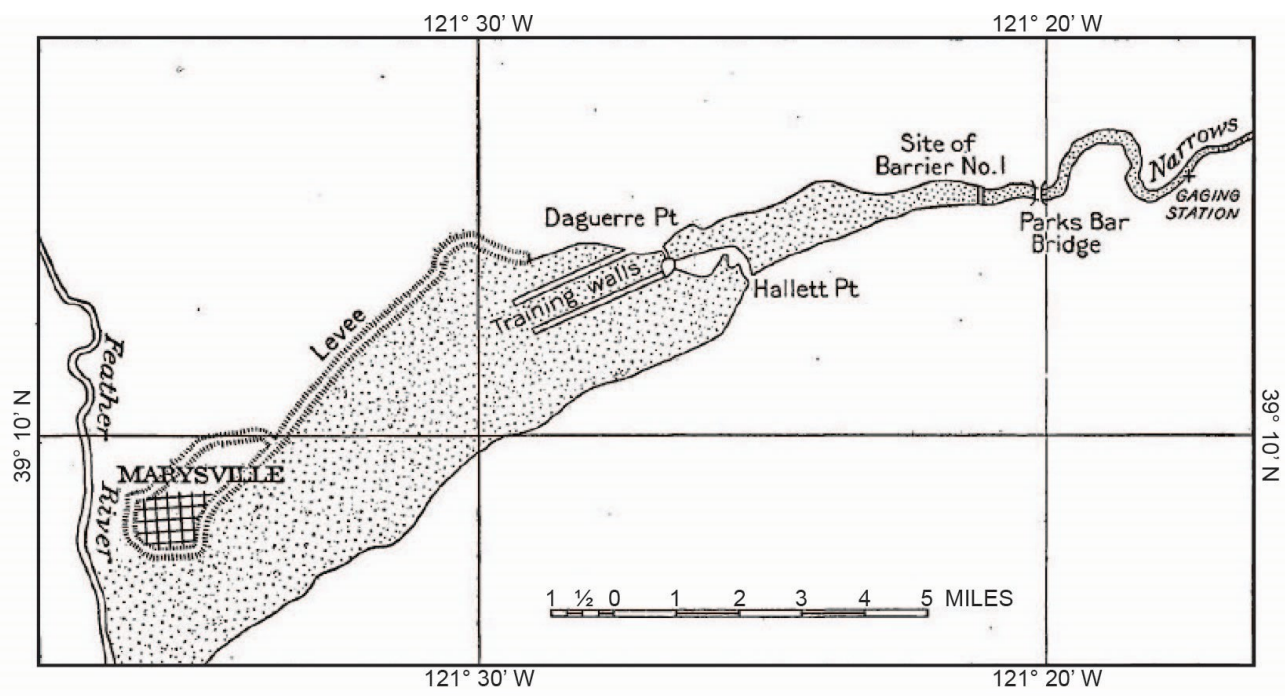

Figure 2. G. K. Gilbert's 1917 map of the extent of the hydraulic mining sediment fan deposits along the Yuba River.

Mercury isotope analyses performed by Donovan et al. (2016) suggest that the mercury contamination that has occurred within the Yuba River watershed is associated with the HMS. Singer et al. (2016) demonstrated that substantial bioaccumulation of monomethylmercury within the food web of the Yuba River has already occurred and that methylation of mercury may even take place along the floodplains as the HMS becomes inundated during flood events. The HMS that has been stored along the Yuba River is essentially a reservoir of toxic material that enters the food web and can have adverse effects on the local ecosystem. In addition, the contaminated sediment can pass downstream into the lowland Central Valley and eventually to the San Francisco Bay-Delta due to erosion during large floods that occur approximately once a decade (Singer et al., 2013).

This study examined the characteristics and quantity of the HMS that make up the lower Yuba Fan (Fig. 3). The sediment samples that I collected were 
measured for mercury concentration. The lower Yuba Fan consists of HMS that has accumulated along the Yuba River from the confluence of the Feather River to the Yuba Goldfields (Figs. 1 and 3) and within the confines of levees built during the 1880s (James et al., 2009; Ghoshal et al., 2010). While there have been some estimates of the volume of the lower Yuba Fan, the geometry of the HMS deposits has been poorly constrained. To provide a more accurate estimate, I used stratigraphic techniques to identify the pre-mining surface.

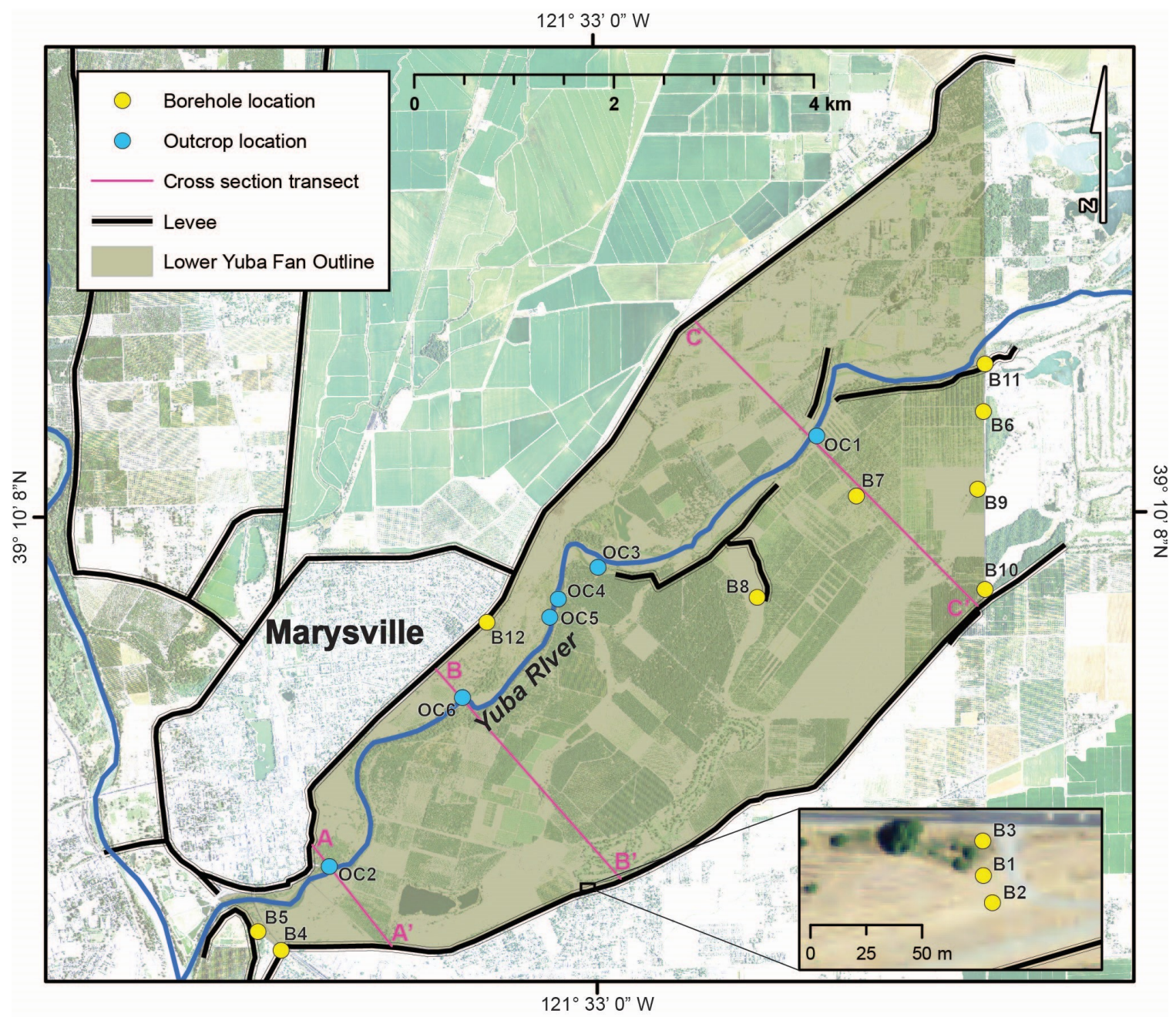

Figure 3. Lower Yuba Fan study area. The map includes sampling locations and cross section transects. Base: Aerial orthoimagery from the USDA (2014a, 2014b, 2014c, 2014d, 2014e, and 2014f). 


\section{MATERIALS AND METHODS}

\section{Sampling Techniques}

Sediment samples were collected from borings and outcrops along the lower Yuba Fan. Boring samples were manually obtained using a stainless steel closed bucket, which was $8.5 \mathrm{~cm}$ in diameter and $18.5 \mathrm{~cm}$ long, attached to a hand auger. The closed cylinder prevents the sample from becoming contaminated with surrounding material within the bore hole. During augering, samples with a minimum mass of $1 \mathrm{~kg}$ were collected at approximately $1-\mathrm{m}$ intervals in each boring. Additional samples were taken when sedimentological changes were detected in the boring spoils. At depths greater than $6 \mathrm{~m}$, sampling by auger was inefficient because the length of the extension rods made it difficult to retain the sediment within the auger bucket when extracting the sample from the borehole. Therefore, the maximum possible augering depth was approximately $6 \mathrm{~m}$. Each borehole was augered until pre-mining deposits were reached or the maximum possible depth was attained. Significant changes in sediment type or color were used as indicators of whether the pre-mining sediment was encountered.

The stratigraphic outcrops along the Yuba River that were surveyed and sampled consisted of cut banks that contained in situ alluvial deposits. The thicknesses of the outcrops were measured using a stadia rod and an eye level. Changes in sediment type and color were documented in the field. Again, 1-kg soil samples were taken at 1-m intervals or where significant sedimentological changes occurred. 


\section{Site Selection}

Sediment samples from 11 boreholes were collected within the lower Yuba Fan between the Yuba River and adjacent levees; six of those boreholes were located close to the levees (Fig. 3). Samples were not collected from borehole B9 because the sediment at the site was too coarse to maintain the samples in the auger bucket. Six outcrops were surveyed and sampled along the Yuba River (Fig. 3). Sampled outcrops were located along the edge of the river where the stream had cut into the banks. Selection of the outcrops depended on how well the in situ alluvial deposits were exposed.

Sediment samples were also collected upstream of the lower Yuba Fan at the Blue Point Mine and Rose Bar (Figs. 1 and 4). The Blue Point Mine exposes in situ auriferous gravels; samples from this site were analyzed for mercury content to reveal the background concentrations of the auriferous gravels within the study area. Rose Bar includes a large terrace consisting of mine tailings associated with the Blue Point Mine (Higson and Singer, 2015). Analyzing the sediment within the terrace outcrop helped determine the mercury concentration of HMS before it was reworked by the Yuba River. 


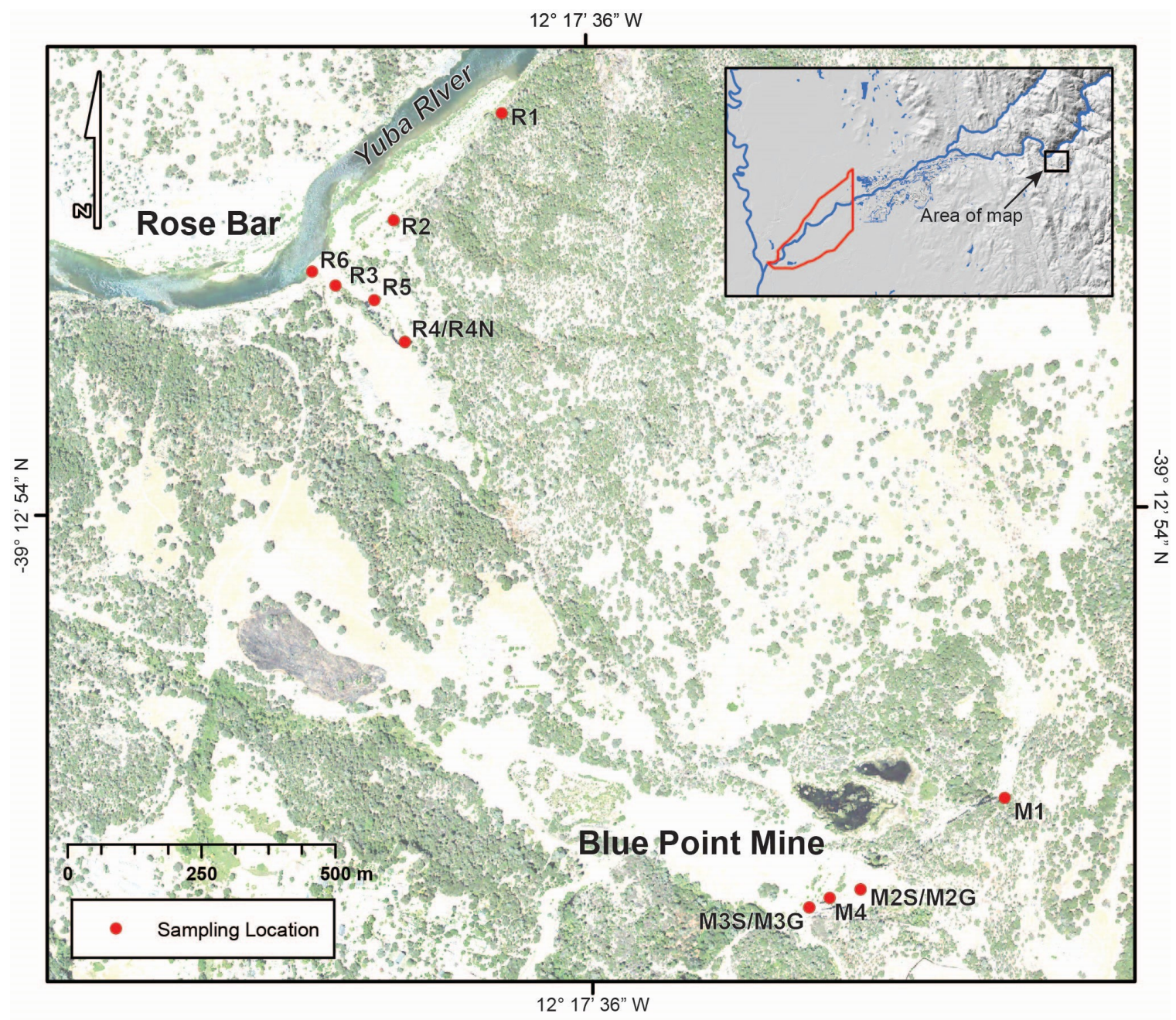

Figure 4. Sampling locations at Blue Point Mine and Rose Bar.

Base: Aerial orthoimagery from the USDA (2014g).

\section{Grain Size Distribution Analysis}

The grain size distribution of each sample was found in order to determine whether certain distributions are unique to either the HMS or pre-mining sediment. The grain size distributions were found using a laboratory test sieve vibrator and Micrometrics SediGraph 5100 Particle Size Analyzer. The following grain sizes were investigated: greater than $2 \mathrm{~mm}$ (gravel), $2 \mathrm{~mm}$ to $62.5 \mu \mathrm{m}$ (sand), $62.5 \mu \mathrm{m}$ to $4 \mu \mathrm{m}$ (silt), and less than $4 \mu \mathrm{m}$ (clay). The fractions of gravel 
and sand were analyzed using the sieve vibrator. The moderately to well indurated soils could not be dry-sieved properly due to low friability. For these samples, I performed a wet-sieve analysis to examine the fine-grained fraction of the sample using a $63 \mu \mathrm{m}$ sieve. The material caught on the sieve was dried, and a dry-sieve analysis was performed. The sediment that passed through the 63 $\mu \mathrm{m}$ sieve was analyzed using the Sedigraph to determine the distribution of silt and clay in each sample.

\section{Mercury Concentration Analysis}

Fine-grained fractions of the samples were also obtained for mercury analysis. To prevent mercury cross-contamination between samples, I used stainless steel sieves. After each sieve analysis, the sieves were washed with isopropyl alcohol and deionized water.

The fine-grained samples collected for the mercury analysis were analyzed in the USGS Mercury Lab at Menlo Park, CA, under the auspices of Dr. Mark Marvin-Pasquale using the EPA Method 1631 for solids preparation and analysis for total mercury via cold vapor atomic fluorescence mass spectrometer (Olund et al., 2005). The minimum mercury concentrations that can be detected range from $0.6 \times 10^{-3} \mathrm{ppm}$ to $0.6 \times 10^{-2} \mathrm{ppm}$. The accuracy of the analysis has been found to range from 85 to 113 percent (Olund et al., 2005).

\section{Chemostratigraphy Analysis}

James et al. (2009) and Singer et al. (2013) found that the contact between the pre-mining deposits and the HMS within stratigraphic sections could be 
identified by an order of magnitude increase in total mercury concentration in the fine-grained fraction of the sediment. The contact between the pre-mining deposits and HMS was located within the borings and stratigraphic columns by identifying areas that had abrupt order-of-magnitude changes in mercury concentration. The contact depths were used to model the geometry of the premining surface using GIS.

\section{Geographic Information Systems Analysis}

The pre-mining surface of the lower Yuba Fan was modeled using ArcGIS 10.4.1 (Environmental Systems Research Institute, 2013). The elevation of the pre-mining surface at each field location was determined by subtracting the depth of the contact between the pre-mining surface and the HMS from the modern surface elevation. The modern surface elevation was found for each field site using a digital elevation model (DEM) from 1999 (Stonestreet and Lee, 2000). The elevation data were interpolated using the 'topo to raster' tool in ArcGIS to create a DEM representing the pre-mining surface. The 'topo to raster' tool uses an algorithm that creates a hydrologically accurate drainage structure while eliminating the presence of large sinks (Hutchinson, 1989).

Digital topographic maps obtained from the USGS were used to create DEMs of the lower Yuba Fan for the years 1911 and 1952 (U.S. Geological Survey, 1911; U.S. Geological Survey, 1952). The topographic maps were georeferenced in ArcGIS using the georeferencing interactive toolset. Multipoint shapefiles were created containing thousands of point features that were placed along the 
contour lines. Each point feature was assigned an elevation that corresponded to the contour line on which it was placed. The shapefiles were converted into raster surfaces using inverse distance weighted (IDW) interpolation. IDW interpolation predicts the elevation of each raster cell within the model grid using surrounding known elevation values. The program assumes that nearby known elevation values have more influence on the elevation prediction than those farther away.

The pre-mining surface, 1911, 1952 and 1999 DEMs were compared using the 'minus' operation in ArcGIS to create maps showing the areas and magnitudes of elevation changes. The 'minus' operation subtracts the cell elevations of the most recent DEM from the cell elevations of the older DEM. Cross sections were generated from the DEMs using the 'stack profile' tool. I used the 'cut-and-fill' operation in ArcGIS to determine the amount of material that had been deposited or removed between different time periods. The 'cutand-fill' operation determines the changes in material volume by using the difference in elevation and the area of each cell.

\section{Mercury Volume and Mass Calculations}

The mass load of mercury within the lower Yuba Fan was calculated from the volume and average mercury concentration of the HMS. I used the HMS volume that the 'cut-and-fill' operation computed between 1852 and 1999. The mercury concentration data reported here are for the fine-grained fraction of the HMS only. I used the average mercury concentration of the sand fraction of the HMS in 
the Yuba Goldfields found by Hunerlach (2004) to calculate the amount of mercury in the sand fraction of the HMS within the lower Yuba Fan. The sediment within the Yuba Goldfields likely has mercury levels similar to those of the HMS found within the lower Yuba Fan because the Yuba Goldfields are located directly upstream of the lower Yuba Fan (Fig. 1). 


\section{RESULTS}

\section{Sampling Location Information}

Sediment samples were collected from 11 borings and 6 outcrops along the lower Yuba Fan (Fig. 3). Tables A1 and A2 contain the site locations, sampling dates, boring depths or outcrop heights, and the number of samples acquired from each site.

Additionally, sediment samples were collected from 6 locations at the Blue Point Mine and 7 locations at Rose Bar (Fig. 4, Table A3). The elevations of the sampling locations were not documented.

\section{Grain Size Distributions}

Figure 5 shows the grain size distribution results plotted on Shepard's classification ternary diagrams (Shepard, 1954; Schlee, 1973). The samples collected from the borings consist of silt, clayey silt, sand silt clay, sandy silt, silty sand, sand, gravelly sediment and gravel. The outcrop samples have the same types of sediment as the boring samples except that they do not contain clayey silt or sand silt clay. The samples collected from Rose Bar and the Blue Point Mine were classified as gravel except for one gravelly sediment sample and two sand samples. 


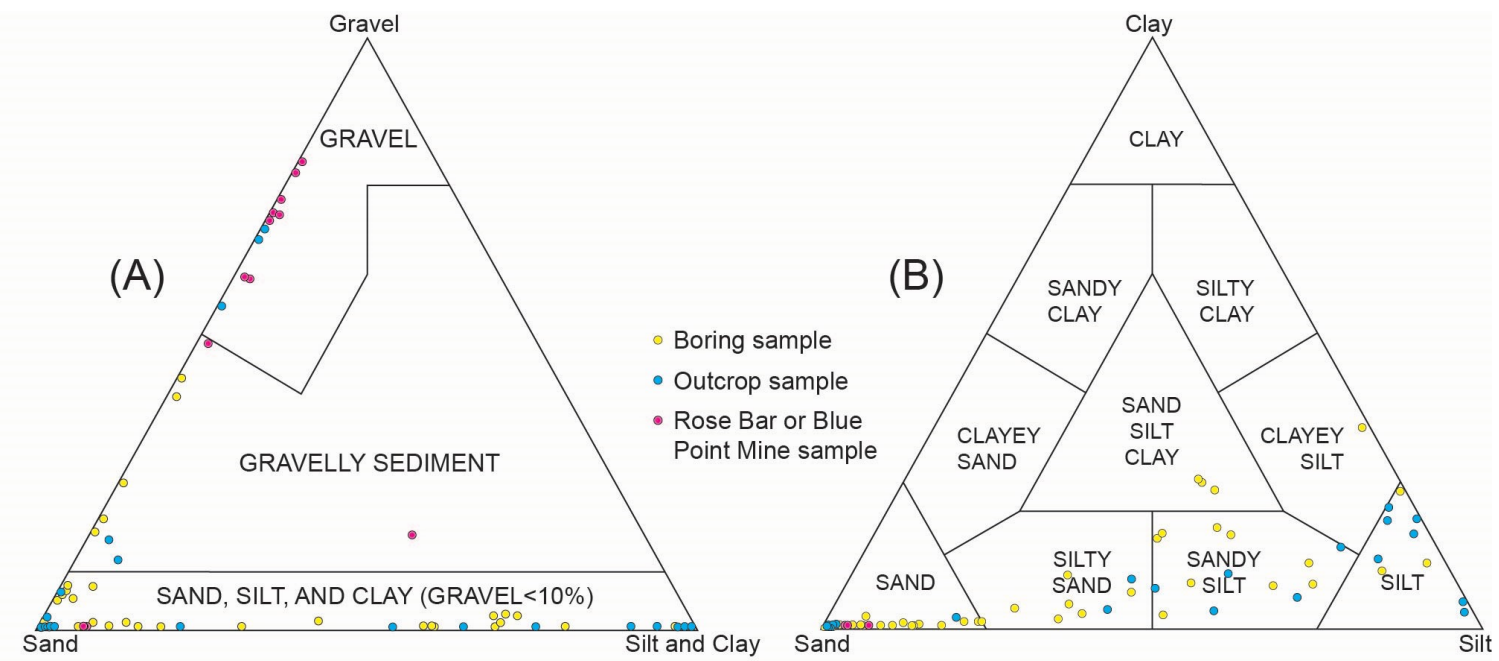

Figure 5. Shepard classification ternary diagrams. Ternary diagram (A) contains all of the sediment samples with an emphasis on samples with more than 10 percent gravel. Ternary diagram (B) includes only samples with less than 10 percent gravel.

\section{Mercury Concentrations}

Figure 6 presents the assay results for all of the sediment samples. The total mercury concentrations of the fine-grained fractions of the sediment samples ranged from about $10^{-2}$ to $10^{0} \mathrm{ppm}$ (mass fraction). Because the outcrops were measured starting from the bottom of each stratigraphic column, the identification numbers of the outcrop samples decrease with increasing depth from the surface.

The mercury concentrations of the in situ Tertiary sediment collected from Blue Point Mine (Fig. 7) are relatively low and are of order $10^{-2} \mathrm{ppm}$. The Rose Bar samples of un-reworked HMS have mercury concentrations predominantly of order $10^{0} \mathrm{ppm}$. Sample R2 has a higher mercury concentration (10.380 ppm) than the rest of the Rose Bar samples, and sample R4N had a relatively low mercury concentration (0.035 ppm). 


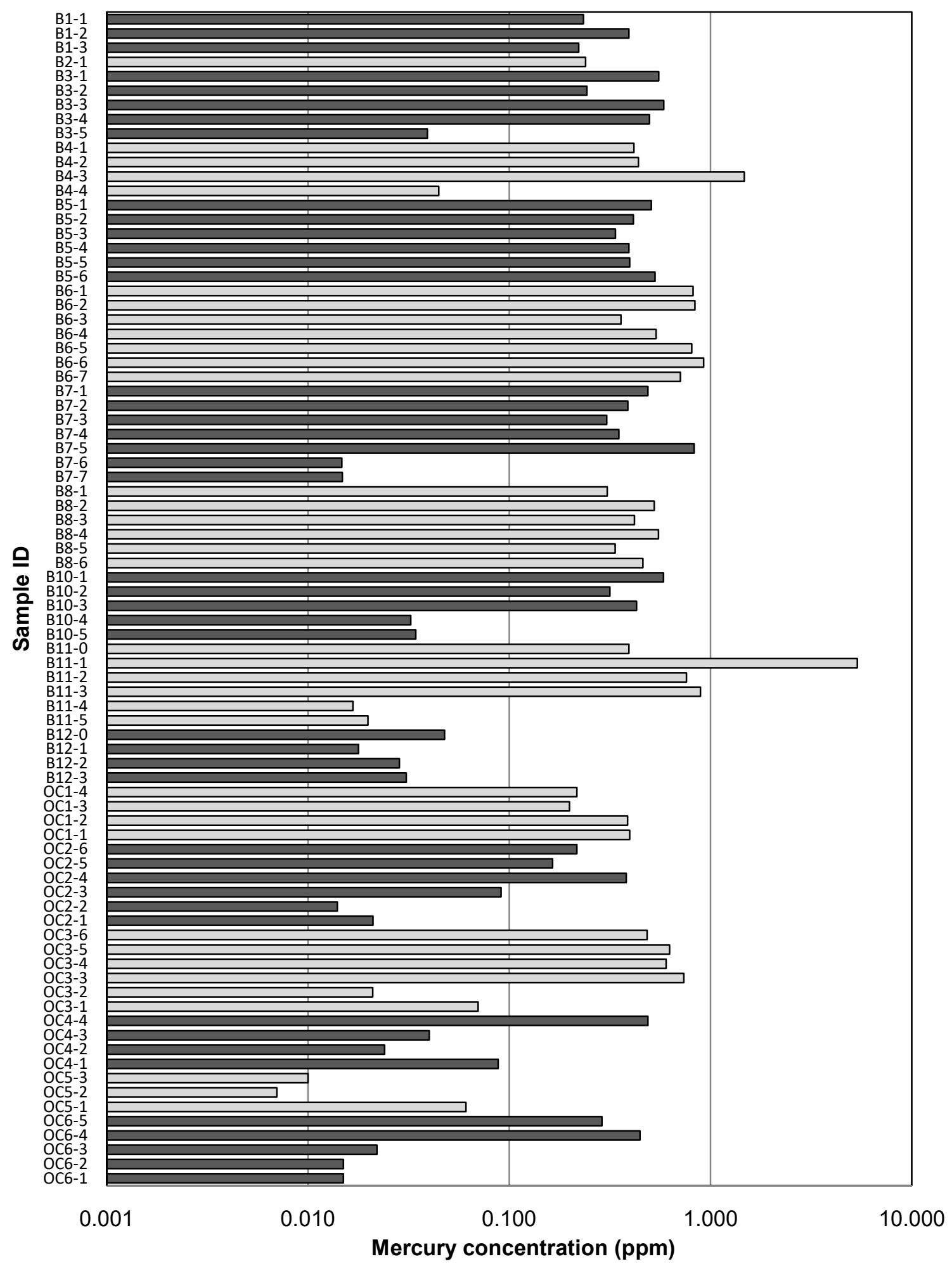

Figure 6. Boring and outcrop sample concentrations in parts per million. 


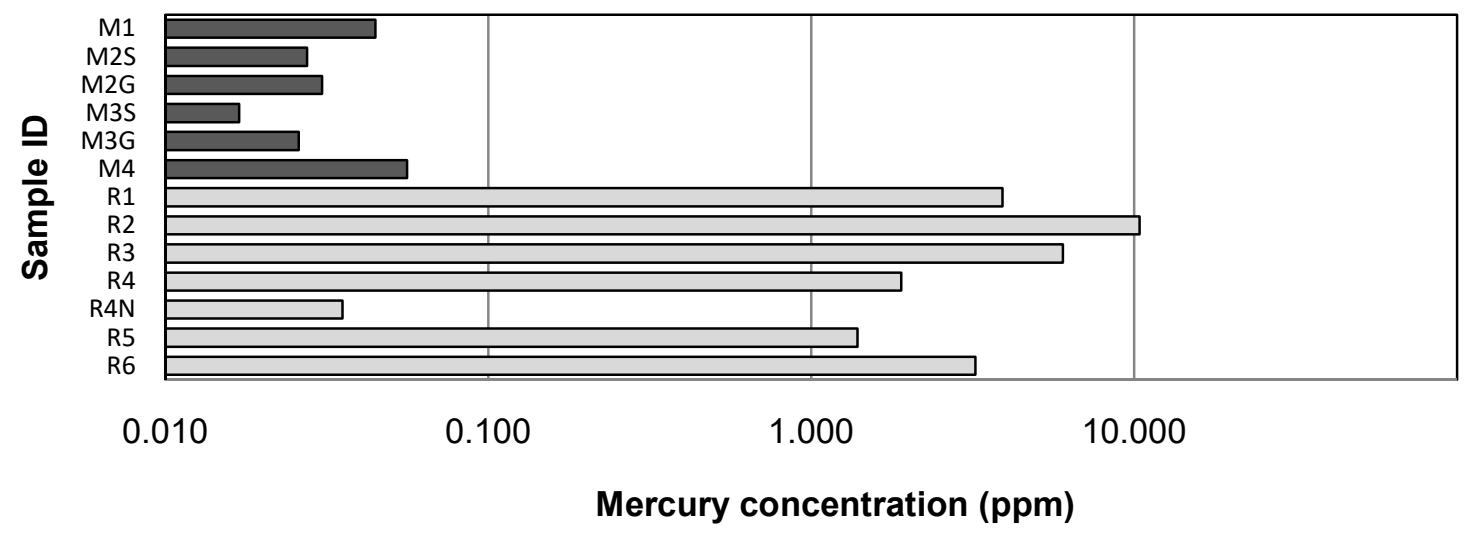

Figure 7. Blue Point Mine and Rose Bar sample mercury concentrations in parts per million.

\section{Chemostratigraphy}

The samples collected at the Blue Point Mine reveal the mercury concentration of the auriferous gravels before being processed with mercury during mining operations. The mercury concentrations range from 0.017 to 0.056 ppm (Fig. 7). These concentration values are similar to the average crustal abundance of mercury of $0.067 \mathrm{ppm}(\mathrm{Cox}, 1989)$ and the pre-mining sediment concentration levels of 0.02 and $0.05 \mathrm{ppm}$ measured within the lower Yuba Fan by James et al. (2009).

The sediment within the fluvial terraces at Rose Bar was analyzed to determine the mercury concentration of the mining sediment after it was processed with mercury and dispersed along the adjacent rivers. Field observations suggested that sample R4N was not HMS because it was collected below the stratigraphic contact between the mine tailings (upper unit) and the native soil (lower unit). This was confirmed by the sample's relatively low mercury concentration of $0.035 \mathrm{ppm}$. The mercury concentrations of the Rose Bar 
samples range from 1.390 to $10.380 \mathrm{ppm}$ (Figure 7). The two orders-ofmagnitude difference between the Blue Point Mine and Rose Bar samples confirms that residual amounts of mercury remained with the mining sediment after the amalgamation process. The large difference in mercury concentration between the auriferous gravels at the Blue Point Mine and the mine tailings along Rose Bar explains the elevated mercury concentration of the sediment downstream of the mine.

The chemostratigraphy of each boring and outcrop along the lower Yuba Fan was evaluated to determine if the contact between the HMS and pre-mining deposits was reached (Tables 1 and 2). Each site's mercury concentrations were analyzed to establish whether the pre-mining sediment was found. Samples consisting of pre-mining sediment are inferred to have mercury concentrations comparable to the samples collected at the Blue Point Mine (which had an order of magnitude of $10^{-2} \mathrm{ppm}$ ) (Fig. 7). The contact between the pre-mining sediment and the HMS was initially identified where there was at least a ten-fold increase in mercury concentration between two consecutive samples (Tables 1 and 2). If a ten-fold increase was found between adjacent samples, stratigraphic boundaries documented during sampling were used to determine the exact depth of the contact between the pre-mining sediment and HMS. Field observations indicated that the $\mathrm{OC} 1$ samples consist of colluvium deposited along the outcrop's surface instead of in situ fluvial deposits; therefore, the contact depth from James et al. (2009) was used because the sampling location was close to the stratigraphic 
column that they sampled near the USGS stream gage (station number: 11421000).

The contact between the pre-mining sediment and HMS was found in 5 borings and 4 outcrops (Tables 1 and 2 ). Contacts within the outcrops are generally abrupt except for a gradational contact found within OC6.

Table 1. Boring chemostratigraphy analysis results. The dashed lines in the mercury concentration column indicate the location of the contact between the HMS and pre-mining sediment within the boreholes. The bold mercury concentration values are the pre-mining sediment mercury concentrations.

\begin{tabular}{|c|c|c|c|c|}
\hline Sample ID & $\begin{array}{l}\text { Depth } \\
\text { (m) }\end{array}$ & $\begin{array}{l}\text { Sediment } \\
\text { classification }\end{array}$ & $\begin{array}{l}\text { Mercury concentration } \\
\text { (parts per million) }\end{array}$ & Contact depth (m) \\
\hline B1-1 & 0.15 & Gravelly sediment & 0.234 & \multirow{3}{*}{ Not reached } \\
\hline B1-2 & 0.40 & Gravelly sediment & 0.393 & \\
\hline B1-3 & 0.52 & Sandy silt & 0.222 & \\
\hline $\mathrm{B} 2-1$ & 0.15 & Sand & 0.240 & \multirow[t]{6}{*}{ Not reached } \\
\hline B3-1 & 0.35 & Sand & 0.553 & \\
\hline B3-2 & 0.66 & Gravelly sediment & 0.243 & \\
\hline B3-3 & 0.84 & Sandy silt & 0.586 & \\
\hline B3-4 & 1.16 & Sand & 0.497 & \\
\hline B3-5 & 1.51 & Sand silt slay & 0.039 & \\
\hline B4-1 & 0.40 & Gravelly sediment & 0.416 & \multirow{4}{*}{1.85} \\
\hline B4-2 & 0.86 & Gravelly sediment & 0.438 & \\
\hline B4-3 & 1.37 & Sand & 1.470 & \\
\hline B4-4 & 1.95 & Sandy silt & 0.045 & \\
\hline B5-1 & 0.71 & Sand & 0.509 & \multirow{6}{*}{ Not reached } \\
\hline B5-2 & 1.40 & Sand & 0.414 & \\
\hline B5-3 & 1.83 & Sandy silt & 0.337 & \\
\hline B5-4 & 2.70 & Silt & 0.393 & \\
\hline B5-5 & 3.28 & Sand & 0.396 & \\
\hline B5-6 & 4.35 & Silty sand & 0.531 & \\
\hline B6-1 & 0.48 & Sand & 0.818 & \multirow{7}{*}{$\begin{array}{l}\text { Water table encountered at } \\
5.75 \mathrm{~m} \text {, contact not reached }\end{array}$} \\
\hline B6-2 & 1.50 & Sand & 0.835 & \\
\hline B6-3 & 2.52 & Silty sand & 0.359 & \\
\hline B6-4 & 3.50 & Sand & 0.537 & \\
\hline B6-5 & 4.50 & Silty sand & 0.808 & \\
\hline B6-6 & 5.60 & Sand & 0.923 & \\
\hline B6-7 & 5.90 & Sandy silt & 0.708 & \\
\hline
\end{tabular}


Table 1. Continued

\begin{tabular}{|c|c|c|c|c|}
\hline B7-1 & 0.14 & Silty sand & 0.488 & \multirow{7}{*}{2.80} \\
\hline B7-2 & 0.60 & Silt & 0.389 & \\
\hline B7-3 & 1.57 & Clayey silt & 0.305 & \\
\hline B7-4 & 2.48 & Silt & 0.351 & \\
\hline B7-5 & 2.66 & Sand & 0.830 & \\
\hline B7-6 & 3.10 & Sandy silt & 0.015 & \\
\hline B7-7 & 4.08 & Silty sand & 0.015 & \\
\hline B8-1 & 0.57 & Sand & 0.307 & \multirow{6}{*}{ Not reached } \\
\hline B8-2 & 1.66 & Sand & 0.525 & \\
\hline B8-3 & 2.56 & Sand & 0.419 & \\
\hline B8-4 & 3.63 & Sand & 0.551 & \\
\hline B8-5 & 4.60 & Sand & 0.336 & \\
\hline B8-6 & 5.43 & Sand & 0.461 & \\
\hline B10-1 & 0.74 & Sand & 0.584 & \multirow{5}{*}{3.14} \\
\hline B10-2 & 1.12 & Sand & 0.316 & \\
\hline B10-3 & 2.45 & Sand & 0.429 & \\
\hline B10-4 & 3.40 & Sand silt clay & 0.032 & \\
\hline B10-5 & 3.56 & Sand silt clay & 0.034 & \\
\hline B11-0 & 0.60 & Sand & 0.393 & \multirow{6}{*}{5.45} \\
\hline B11-1 & 2.40 & Sand & 5.362 & \\
\hline B11-2 & 3.35 & Sand & 0.759 & \\
\hline B11-3 & 4.37 & Sandy silt & 0.892 & \\
\hline B11-4 & 5.75 & Silty sand & 0.017 & \\
\hline B11-5 & 6.47 & Silty sand & 0.020 & \\
\hline B12-0 & 0.00 & Sand & 0.048 & \multirow{4}{*}{ Not reached } \\
\hline B12-1 & 0.10 & Sand & 0.018 & \\
\hline B12-2 & 0.40 & Sandy silt & 0.028 & \\
\hline B12-3 & 0.60 & Sandy silt & 0.031 & \\
\hline
\end{tabular}


Table 2. Outcrop chemostratigraphy analysis results. The dashed lines in the mercury concentration column indicate the location of the contact between the HMS and pre-mining sediment within the outcrops. The bold mercury concentration values are the pre-mining sediment mercury concentrations.

\begin{tabular}{|c|c|c|c|c|}
\hline Sample ID & $\begin{array}{l}\text { Depth } \\
\text { (m) }\end{array}$ & $\begin{array}{l}\text { Sediment } \\
\text { classification }\end{array}$ & $\begin{array}{l}\text { Mercury concentration } \\
\text { (parts per million) }\end{array}$ & Contact depth $(\mathrm{m})$ \\
\hline OC1-4 & 2.10 & Sand & 0.217 & \multirow{4}{*}{$\begin{array}{c}7.00 \\
\text { (James et al. 2009) }\end{array}$} \\
\hline OC1-3 & 3.78 & Sand & 0.199 & \\
\hline OC1-2 & 5.51 & Gravelly sediment & 0.387 & \\
\hline OC1-1 & 7.13 & Gravelly sediment & 0.397 & \\
\hline OC2-6 & 1.64 & Sandy silt & 0.217 & \multirow{6}{*}{4.02} \\
\hline OC2-5 & 3.20 & Sandy silt & 0.164 & \\
\hline OC2-4 & 3.81 & Silty sand & 0.381 & \\
\hline oc2-3 & 4.42 & Sandy silt & 0.091 & \\
\hline OC2-2 & 5.64 & Silty sand & 0.014 & \\
\hline OC2-1 & 6.25 & Gravel & 0.021 & \\
\hline OC3-6 & 2.50 & Silt & 0.484 & \multirow{6}{*}{7.53} \\
\hline OC3-5 & 3.57 & Sand & 0.625 & \\
\hline OC3-4 & 5.40 & Sand & 0.601 & \\
\hline oc3-3 & 7.20 & Silt & 0.736 & \\
\hline oc3-2 & 7.74 & Sandy silt & 0.021 & \\
\hline OC3-1 & 8.45 & Gravel & 0.070 & \\
\hline OC4-4 & 4.60 & Sand & 0.489 & \multirow{4}{*}{6.81} \\
\hline OC4-3 & 7.40 & Silt & 0.040 & \\
\hline OC4-2 & 9.57 & Sand & 0.024 & \\
\hline OC4-1 & 11.15 & Sand & 0.088 & \\
\hline OC5-3 & 2.22 & Silt & 0.010 & \multirow{3}{*}{ Not reached } \\
\hline OC5-2 & 4.05 & Sandy silt & 0.007 & \\
\hline OC5-1 & 6.49 & Gravel & 0.061 & \\
\hline Oc6-5 & 0.61 & Sand & 0.289 & \multirow{5}{*}{5.63} \\
\hline OC6-4 & 3.20 & Sand & 0.446 & \\
\hline OC6-3 & 6.40 & Silt & 0.022 & \\
\hline oc6-2 & 8.17 & Silt & 0.015 & \\
\hline OC6-1 & 9.51 & Silt & 0.015 & \\
\hline
\end{tabular}

The HMS samples have a high percentage of sand samples, and the premining sediment samples are largely silt-rich (Table 3). The majority of the HMS samples have light to pale shades of brown and gray (Table 3), while the premining sediment samples are mainly darker shades of brown. Darker shades of 
brown are highly indicative of the pre-mining sediment while lighter shades of gray and brown are associated with the HMS.

Table 3. Sediment and color classification statistics for hydraulic mining and pre-mining sediment.

\begin{tabular}{|c|c|c|}
\hline \multicolumn{3}{|c|}{ Hydraulic Mining Sediment } \\
\hline Shepard sediment classification & Count & Percent \\
\hline Sand & 31 & $55 \%$ \\
\hline Gravelly Sediment & 7 & $13 \%$ \\
\hline Sandy Silt & 7 & $13 \%$ \\
\hline Silt & 5 & $9 \%$ \\
\hline Silty Sand & 5 & $9 \%$ \\
\hline Clayey Silt & 1 & $2 \%$ \\
\hline Munsell Color classification & Count & Percent \\
\hline Pale Brown or Very Pale Brown & 31 & $55 \%$ \\
\hline Light Yellowish Brown, Light Brownish Gray, or Light Gray & 20 & $36 \%$ \\
\hline Brown or Yellowish Brown & 5 & $9 \%$ \\
\hline \multicolumn{3}{|c|}{ Pre-mining Sediment } \\
\hline Shepard sediment classification & Count & Percent \\
\hline Sandy Silt & 7 & $27 \%$ \\
\hline Silt & 5 & $19 \%$ \\
\hline Silty Sand & 4 & $15 \%$ \\
\hline Sand & 4 & $15 \%$ \\
\hline Sand Silt Clay & 3 & $12 \%$ \\
\hline Gravel & 3 & $12 \%$ \\
\hline Munsell color classification & Count & Percent \\
\hline Brown, Yellowish Brown, or Grayish Brown & 15 & $58 \%$ \\
\hline Dark Grayish Brown or Dark Yellowish Brown & 4 & $15 \%$ \\
\hline Pale Brown & 4 & $15 \%$ \\
\hline Light Gray & 3 & $12 \%$ \\
\hline
\end{tabular}




\section{Historic Surfaces}

Digital elevation models of the lower Yuba Fan's surface were created for the following years: 1852, 1911, 1952, and 1999 using ArcGIS (Fig. 8). Table B1 displays the elevations of the pre-mining surface-HMS contact that I calculated.

1852

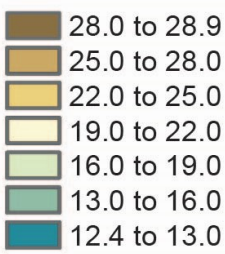

$\uparrow$

28.0 to 29.3

25.0 to 28.0

22.0 to 25.0

19.0 to 22.0

16.0 to 19.0

13.0 to 16.0

12.2 to 13.0

1952

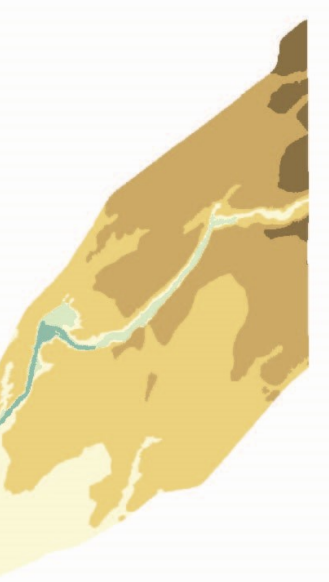

1911

28.0 to 29.0

25.0 to 28.0

22.0 to 25.0

19.0 to 22.0

16.8 to 19.0

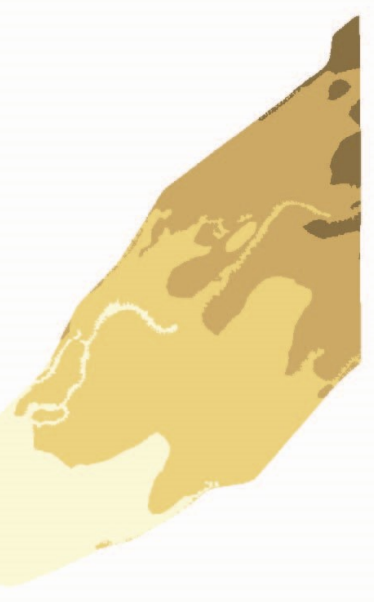

1999

29.6 to 40.2

28.0 to 29.6

25.0 to 28.0

22.0 to 25.0

19.0 to 22.0

16.0 to 19.0

13.0 to 16.0

10.0 to 13.0

6.9 to 10.0

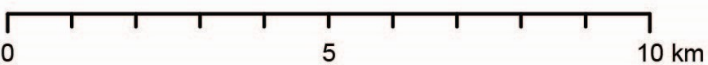

Figure 8. Digital elevation models (DEM) representing the surface of the lower Yuba Fan (Fig. 1) at four points in time. Each DEM has a color ramp displaying the elevation range in meters. 
The 1852 DEM represents the pre-mining surface of the lower Yuba Fan because that was the year in which major hydraulic mining operations began in the Yuba River Watershed.

The topo to raster method was used to create the 1852 DEM from the contact elevations in Table B1. The 1852 DEM has 1-m grid spacing. The extent of the deposits was restricted by levees built along the northern side of the Yuba River in the 1880s (James et al., 2009) (Figs. 2 and 3). Therefore, elevations along the base of the northern levee were identified from the 1999 DEM and were used to recreate the 1852 surface (Fig. 8). The elevations of the 1852 DEM range from12.4 to $28.9 \mathrm{~m}$ above mean sea level (Fig. 8).

For the boreholes with samples consisting entirely of HMS, as a conservative approach, I estimated the depths in which the contacts may be located by subtracting a half meter from the bottom of the boreholes (Table A1 and Table B2), thereby providing a minimum depth for the pre-mining surface. I did not estimate the depth of the contact for boreholes B1 and B2 because the contact was reached at the nearby borehole B3 (Fig. 3). The OC5 outcrop also consisted entirely of pre-mining deposits. Therefore, I assumed that the contact between the HMS and pre-mining deposits was located stratigraphically above the top of the outcrop. The contact elevation within the vicinity of the OC5 outcrop was estimated to be a half meter above the highest sample in the stratigraphic column (Table 2 and Table B2). 
The results of the IDW interpolation of the 1911 and 1952 topographic maps are shown in Figure 8 . The 1911 DEM has elevations that range from 16.8 to $29.0 \mathrm{~m}$, and the 1952 DEM has elevations that range from 12.2 to $29.3 \mathrm{~m}$. The 1999 DEM has an elevation range from 6.9 to $40.2 \mathrm{~m}$ (Fig. 8). The rectangular topographic features in the north central portion of the 1999 DEM are landfills. The highest elevation within the 1999 DEM, excluding the landfills, is $29.6 \mathrm{~m}$.

The amount of elevation change between the DEMs was represented with choropleth maps (Fig. 9). The maps show elevation differences for four different time intervals: 1852 to 1911,1911 to 1952,1952 to 1999 , and 1852 to 1999. Between 1852 and 1911, there was up to $8.1 \mathrm{~m}$ of deposition and $2.4 \mathrm{~m}$ of erosion. During the time period between 1911 and 1952, $3.3 \mathrm{~m}$ of deposition and up to $9.1 \mathrm{~m}$ of incision occurred. The difference map that displays the change in elevation from 1952 to 1999 shows that there were areas where the elevation increased by up to $9.2 \mathrm{~m}$. These areas appear as thin strips of anomalously high elevation increases along the central portion of the map (Fig. 9). The areas of high elevation change are close to the southern bank of the 1999 channel (Fig 9). Field observations revealed that these banks consist of very steep cut banks that are prone to erosion. I assumed that the relatively lower precision of the 1952 topographic map that I used to make the 1952 DEM resulted in less accuracy when modeling the 1952 channel's geometry. Therefore, there appeared to be high rates of deposition near the present channel, when in reality the amount of deposition was more than likely not as severe. By nullifying these high elevation 
increase areas in ArcGIS, I found that a maximum of $3.3 \mathrm{~m}$ of deposition had occurred within the study area between 1952 and 1999. The difference map also shows that up to $9.4 \mathrm{~m}$ of erosion occurred from 1952 to 1999.

\section{2 to 1911}
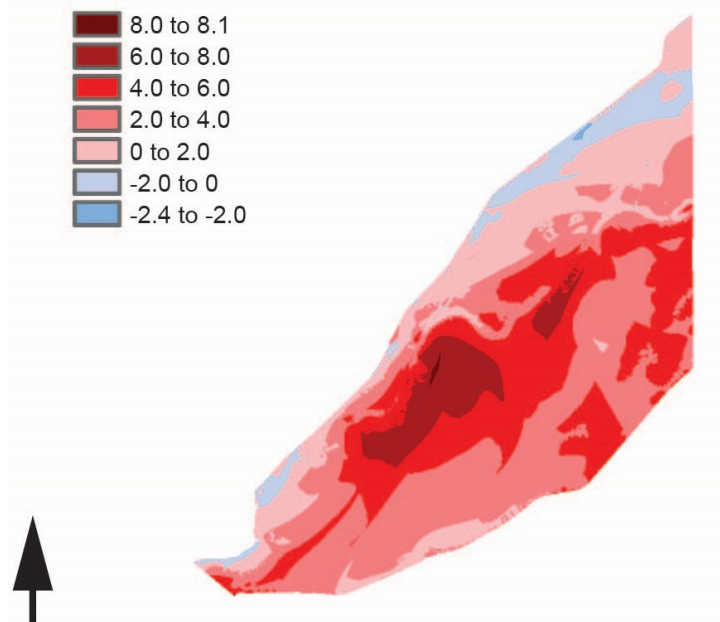

1952 to 1999

$\mathbf{N}$

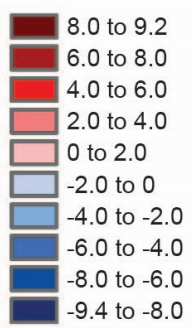

1911 to 1952

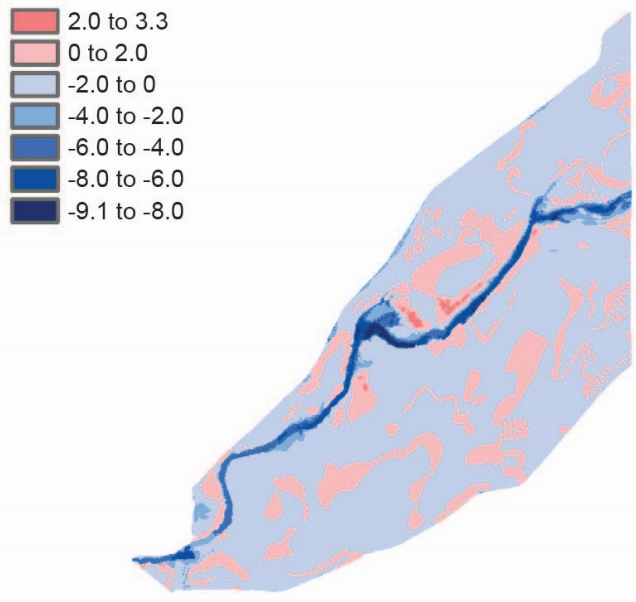

1852 to 1999

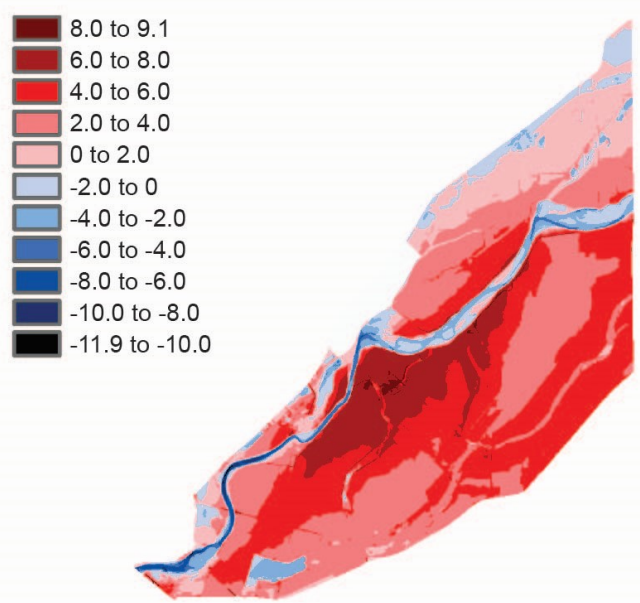

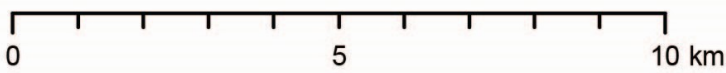

Flgure 9. Maps showing the change in elevation in meters for the following time intervals: 1852 to 1911,1911 to 1952,1952 to 1999 , and 1852 to 1999.

The final difference map shows that between 1852 and 1999 there was up to $9.1 \mathrm{~m}$ of deposition and $11.9 \mathrm{~m}$ of surface erosion. The elevation difference maps 
for the 1952 to 1999 and 1852 to 1999 time intervals do not include the area where the present day landfill is located in the north central portion of the map, because my goal was to solely quantify the amount of elevation change caused by erosion or deposition associated with fluvial processes.

Cross sections across the fan (Fig. 3) were created from the DEMs (Figs. 10 12). Each cross section contains the surface profiles for the years 1852, 1911, 1952, and 1999. The cross sections show the changes in elevation that occurred along each transect since 1852.

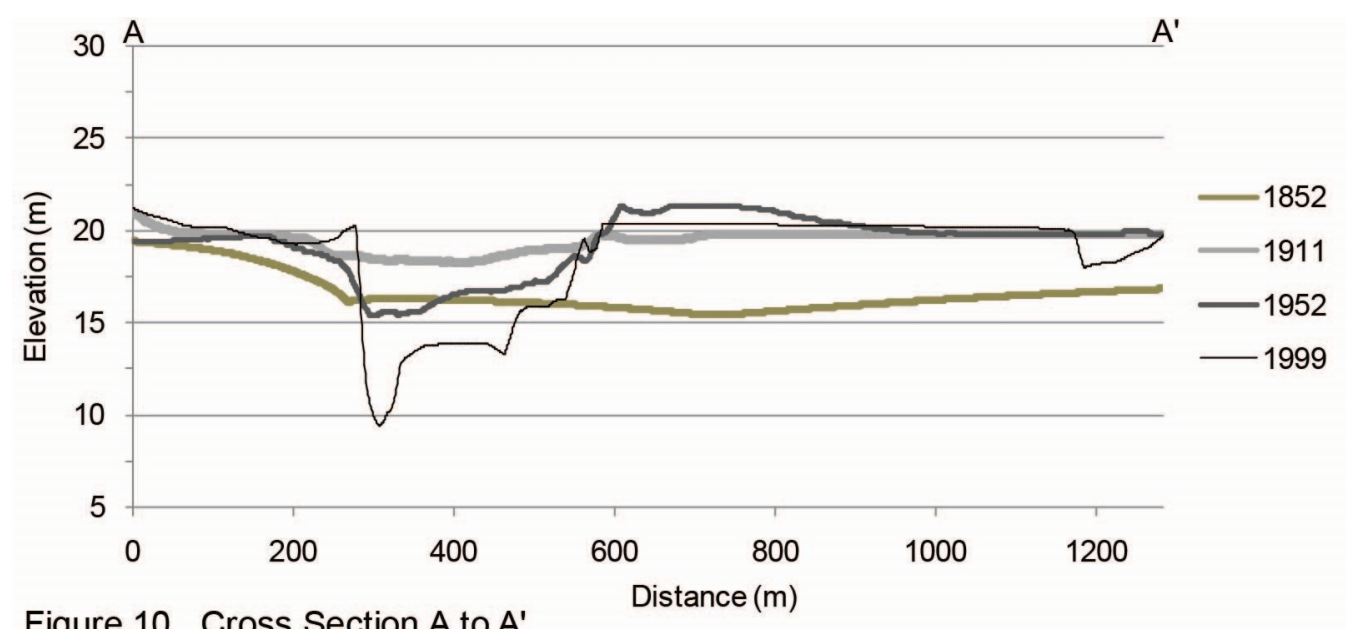

Figure 10. Cross Section A to A'.

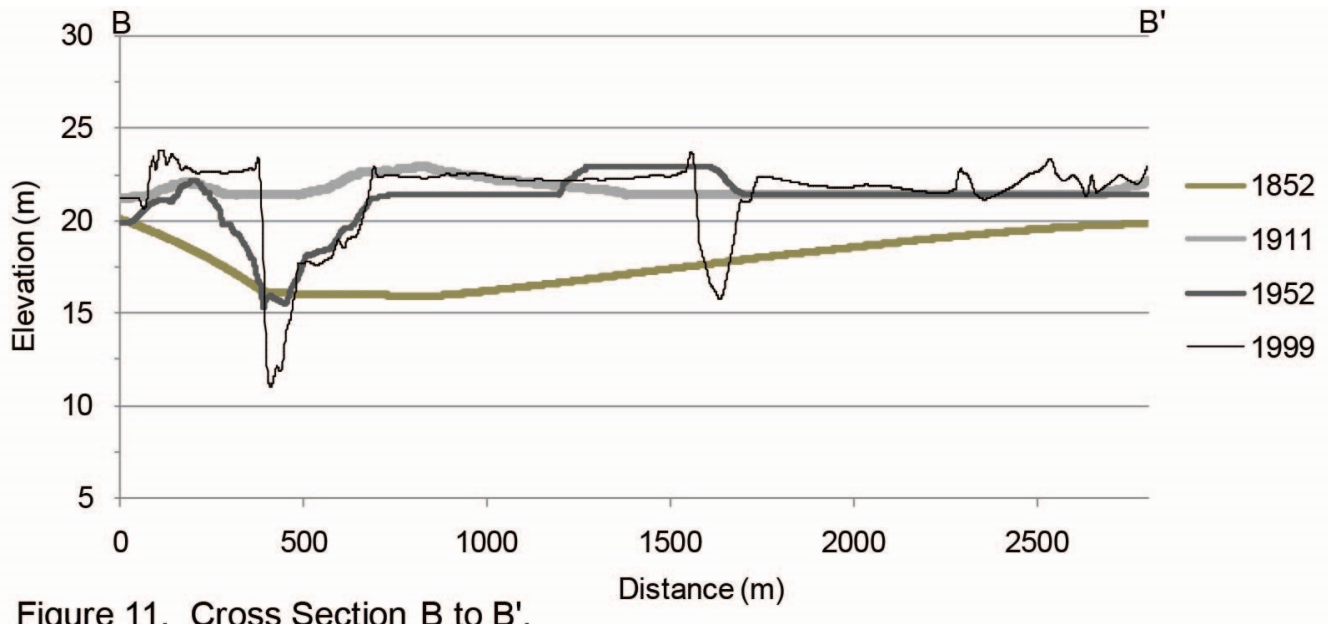

Figure 11. Cross Section B to B'. 


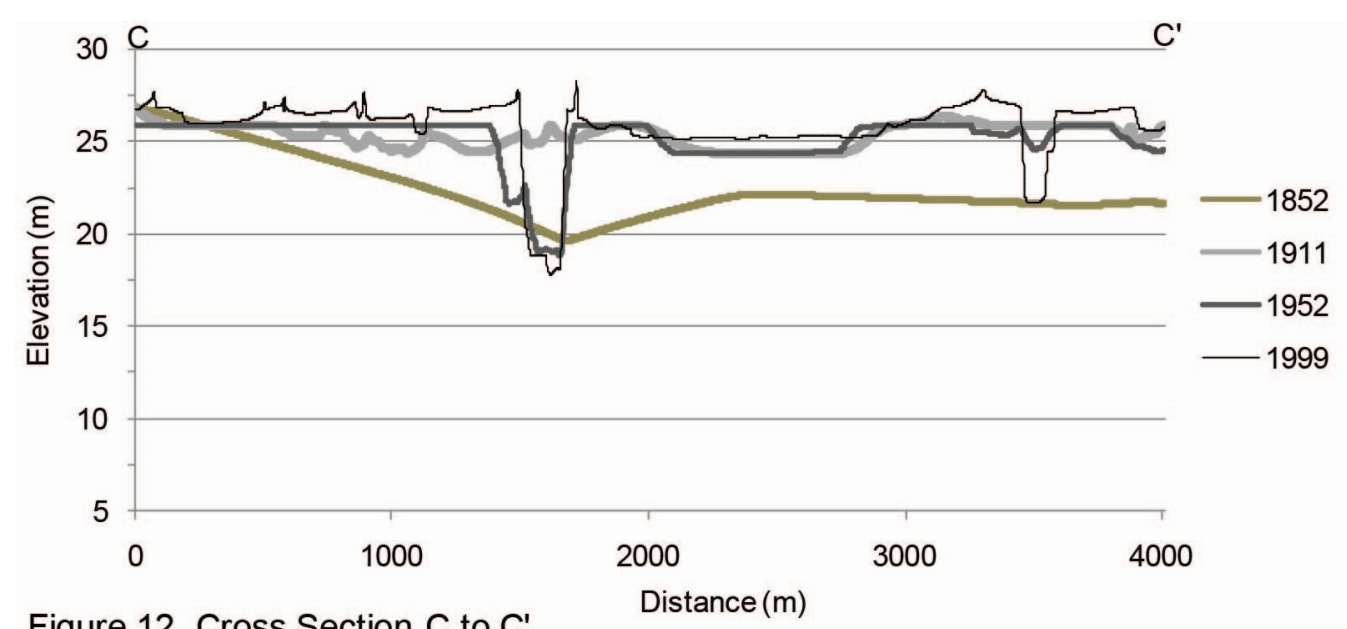

Figure 12. Cross Section $C$ to $C^{\prime}$.

\section{Amount of Erosion and Deposition}

Changes in material volume for the following time periods, 1852 to 1911 , 1911 to 1952,1952 to 1999 , and 1852 to 1999 , were computed using ArcGIS (Fig. 13). Table 4 contains a summary of the cut-and-fill results. I found that $9.19 \times 10^{7} \mathrm{~m}^{3}$ of material were deposited within the study area from 1852 to 1911. Between 1911 and $1952,9.13 \times 10^{6} \mathrm{~m}^{3}$ of material were eroded from the lower Yuba Fan, and $7.29 \times 10^{6} \mathrm{~m}^{3}$ of material were deposited between 1952 and 1999. The sum of the net changes between 1852 and 1999 was $9.01 \times 10^{7}$ $\mathrm{m}^{3}$ of deposited material while the cut-and-fill analysis results between the 1852 and 1999 DEMs show $8.99 \times 10^{7} \mathrm{~m}^{3}$ of deposited material (Table 4). 
1852 to 1911

Net change $=9.19 \times 10^{7}$ cubic meters

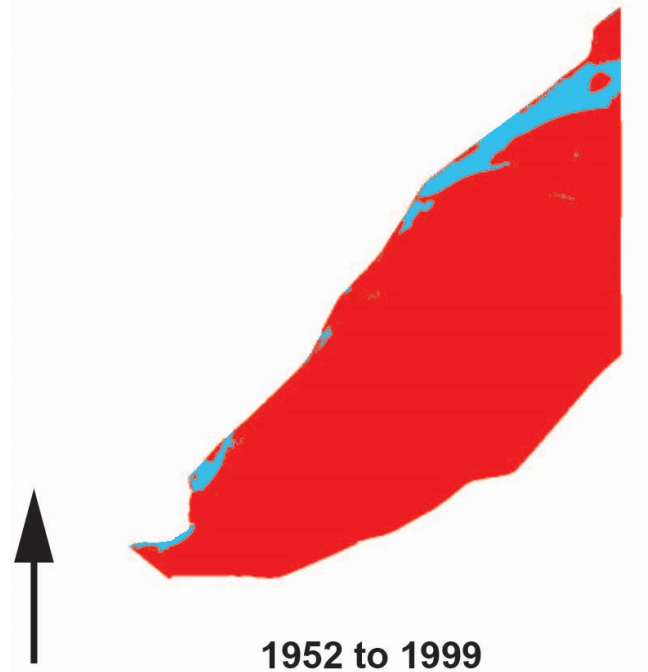

$\mathbf{N}$
Net change $=7.29 \times 10^{6}$ cubic meters

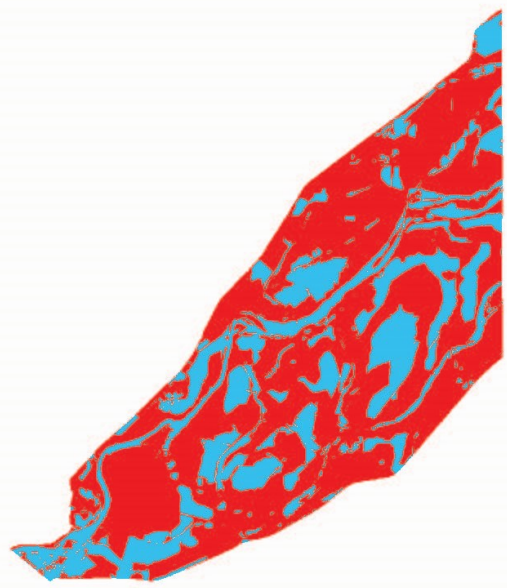

Deposition

No change

Erosion
1911 to 1952

Net change $=-9.13 \times 10^{6}$ cubic meters

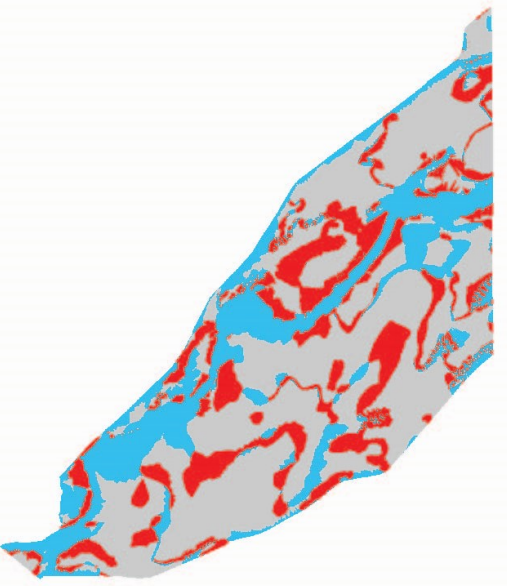

1852 to 1999

Net change $=8.99 \times 10^{7}$ cubic meters

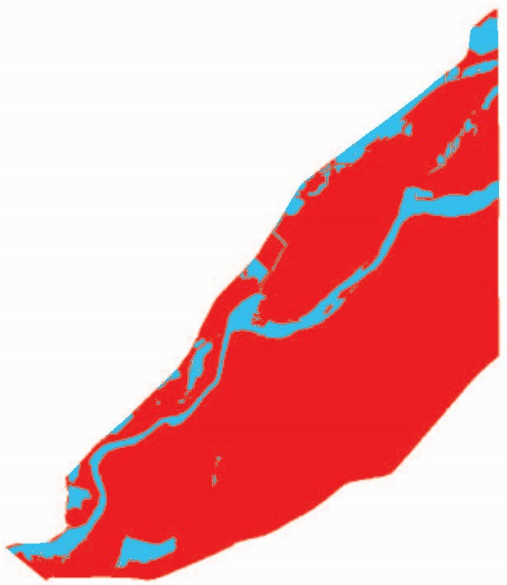

Flgure 13. Maps showing areas of deposition and erosion during specified time intervals. The net change in sediment volume is included with each map.

Table 4. Summary of the cut-and-fill operation results

\begin{tabular}{lccc}
\hline Time interval & Deposited material $\left(\mathbf{m}^{3}\right)$ & Eroded material $\left(\mathbf{m}^{3}\right)$ & Net change $\left(\mathbf{m}^{3}\right)$ \\
\hline 1852 to 1911 & $9.28 \times 10^{7}$ & $9.18 \times 10^{5}$ & $9.19 \times 10^{7}$ \\
1911 to 1952 & $5.17 \times 10^{6}$ & $1.43 \times 10^{7}$ & $-9.13 \times 10^{6}$ \\
1952 to 1999 & $1.73 \times 10^{7}$ & $1.00 \times 10^{7}$ & $7.29 \times 10^{6}$ \\
Sum of net changes & --- & - & $9.01 \times 10^{7}$ \\
from 1852 to 1999 & ---- & $8.99 \times 10^{7}$ \\
1852 to 1999 & $9.68 \times 10^{7}$ & $6.92 \times 10^{6}$ &
\end{tabular}




\section{Total Volume and Mass of Mercury in the Lower Yuba Fan}

The amount of mercury within the HMS of the lower Yuba Fan was estimated using the volume of HMS deposited between 1852 and $1999\left(8.99 \times 10^{7} \mathrm{~m}^{3}\right.$, Table 4). The amount of mercury within the fine-grained fraction of the HMS is much greater than that in the coarser grain size fractions (Hunerlach, 2004). I used the measured grain size distribution (Fig. 5) to calculate the average gravel, sand, and fine-grained fractions of the HMS sampled from the boreholes and outcrops within the lower Yuba Fan. The average fractions of gravel, sand, and fine-grained sediment are $4.01 \%, 68.87 \%$, and $27.12 \%$ respectively. The grain size fractions were used to calculate the total volume of gravel, sand, and finegrained sediment within the lower Yuba Fan (Equations 1 - 3).

Volume of gravel: $\left(8.99 \times 10^{7} \mathrm{~m}^{3}\right) \times(0.0401)=3.60 \times 10^{6} \mathrm{~m}^{3}$

Volume of sand: $\left(8.99 \times 10^{7} \mathrm{~m}^{3}\right) \times(0.6887)=6.19 \times 10^{7} \mathrm{~m}^{3}$

Volume of fines: $\left(8.99 \times 10^{7} \mathrm{~m}^{3}\right) \times(0.2712)=2.44 \times 10^{7} \mathrm{~m}^{3}$

The average mercury concentration of the fine-grained HMS from the lower Yuba Fan is $0.4880 \mathrm{ppm}$ or $4.88 \times 10^{-7} \frac{\mathrm{g} \mathrm{Hg}}{\mathrm{g} \mathrm{HMS}}$. The average mercury concentration of the sand fraction found by Hunerlach (2004) was $0.0223 \mathrm{ppm}$ or $2.23 \times 10^{-8} \frac{\mathrm{g} \mathrm{Hg}}{\mathrm{g} \mathrm{HMS}}$. I assumed that the mercury concentration of the gravel fraction was zero because there are no relevant datasets and the surface to volume ratio of the gravel is relatively low. I used the densities of mercury and HMS in order to 
convert the mass fractions into volume fractions (Equations 4 and 5). The density of mercury is $1.3534 \times 10^{7} \mathrm{~g} / \mathrm{m}^{3}$. The bulk density of the soil within the lower Yuba Fan is $1.65 \times 10^{6} \mathrm{~g} / \mathrm{m}^{3}$ (Soil Survey Staff).

Conversion of average $\mathrm{Hg}$ concentration in sand from mass ratio to volume ratio:

$\frac{2.23 \times 10^{-8} \mathrm{~g} \text { of Hg}}{\mathrm{g} \text { of HMS }} \times \frac{1 \mathrm{~m}^{3} \text { of Hg }}{1.3534 \times 10^{7} \mathrm{~g} \text { of Hg}} \times \frac{1.65 \times 10^{6} \mathrm{~g} \text { of HMS }}{\mathrm{m}^{3} \text { of } \mathrm{HMS}}=2.72 \times 10^{-9} \frac{\mathrm{m}^{3} \text { of Hg}}{\mathrm{m}^{3} \text { of } \mathrm{HMS}}$

Conversion of average $\mathrm{Hg}$ concentration in fines from mass ratio to volume ratio:

$\frac{4.88 \times 10^{-8} \mathrm{~g} \text { of Hg}}{\mathrm{g} \text { of HMS }} \times \frac{1 \mathrm{~m}^{3} \text { of Hg }}{1.3534 \times 10^{7} \mathrm{~g} \text { of Hg}} \times \frac{1.65 \times 10^{6} \mathrm{~g} \text { of HMS }}{\mathrm{m}^{3} \text { of } \mathrm{HMS}}=5.95 \times 10^{-9} \frac{\mathrm{m}^{3} \text { of Hg}}{\mathrm{m}^{3} \text { of } \mathrm{HMS}}$

The volumes of the sand and fine-grained fractions within the HMS (Equations 2 and 3 ) were multiplied by the mercury concentration volume ratios (Equations 4 and 5 ) to determine the volume of mercury in the sand and finegrained fractions of the HMS (Equations 6 and 7 ). The gravel fraction was not analyzed since I assumed that the mercury levels within the gravel were negligible.

Volume of $\mathrm{Hg}$ in the sand fraction of the lower Yuba Fan:

$6.19 \times 10^{7} \mathrm{~m}^{3}$ of $\mathrm{HMS} \times \frac{2.72 \times 10^{-9} \mathrm{~m}^{3} \text { of } \mathrm{Hg}}{\mathrm{m}^{3} \text { of } \mathrm{HMS}}=0.168 \mathrm{~m}^{3}$ of $\mathrm{Hg}$

Volume of $\mathrm{Hg}$ in the fine-grained fraction of the lower Yuba Fan:

$2.44 \times 10^{7} \mathrm{~m}^{3}$ of $\mathrm{HMS} \times \frac{5.95 \times 10^{-9} \mathrm{~m}^{3} \text { of } \mathrm{Hg}}{\mathrm{m}^{3} \text { of } \mathrm{HMS}}=0.145 \mathrm{~m}^{3}$ of $\mathrm{Hg}$ 
The volume of the mercury within the sand fraction was added to the volume of the mercury within the fine-grained fraction to find the total volume of mercury within the HMS of the lower Yuba Fan (Equation 8). The total volume of mercury within the lower Yuba Fan was then multiplied by the density of mercury in order to determine its total mass (Equation 9). The results of the calculations suggest that approximately $0.313 \mathrm{~m}^{3}$ or $4.24 \times 10^{3} \mathrm{~kg}$ of mercury is adsorbed onto the HMS of the lower Yuba Fan.

Total volume of $\mathrm{Hg}$ in the lower Yuba Fan:

$0.168 \mathrm{~m}^{3}$ of $\mathrm{Hg}+0.145 \mathrm{~m}^{3}$ of $\mathrm{Hg}=0.313 \mathrm{~m}^{3}$ of $\mathrm{Hg}$

Total mass of $\mathrm{Hg}$ in the lower Yuba Fan:

$0.313 \mathrm{~m}^{3}$ of $\mathrm{Hg} \times \frac{1.3534 \times 10^{4} \mathrm{~kg}}{\mathrm{~m}^{3}}=4.24 \times 10^{3} \mathrm{~kg}$ of Hg 


\section{DISCUSSION}

The characteristics of the auriferous gravels collected at the Blue Point Mine and the mining sediment at Rose Bar provide insight into the geomorphic history of the region since the onset of hydraulic mining in 1852. Because the Blue Point Mine is located upstream of the lower Yuba Fan (Fig. 1), I assumed that the lower Yuba Fan contains sediment derived from the auriferous gravels. The auriferous gravels within the outcrops of the Blue Point Mine consist of in situ Tertiary deposits that have not been processed with mercury. The mercury concentrations of the auriferous gravels ranges from 0.017 to $0.056 \mathrm{ppm}$ (Fig. 7). Therefore, the pre-mining sediment that underlies the HMS within the lower Yuba Fan should have mercury levels comparable to the Tertiary gravels found at the Blue Point Mine.

The sediment collected at Rose Bar consists of gravel and sand similar to the gravel-rich sediment observed at the Blue Point Mine (Fig. 5). Therefore, the material that currently forms the fluvial terraces at Rose Bar consists of the mine tailings from when the Blue Point Mine was still active. The fine-grained fraction of the sediment found at Rose Bar has mercury concentrations ranging from 1.390 to $10.380 \mathrm{ppm}$, which are two to three orders of magnitude higher than the sediment found at the Blue Point Mine. Thus, the placer deposits mined at Blue Point Mine were contaminated with mercury during the amalgamation process and then dispersed along the small drainages that join the Yuba River. The mine tailings eventually formed the terraces along the Yuba River at Rose Bar, where 
they remain available to be transported downstream and stored along floodplains and in channel deposits.

The chemostratigraphy of the boreholes and outcrops in the downstream part of the Yuba Fan reveal abrupt increases in mercury concentrations. These concentration increases mark the contact between the pre-mining sediment and the HMS. Typically, the mercury concentration of the HMS is one order of magnitude higher in parts per million than the pre-mining sediment (James et al., 2009; Singer et al., 2013). The sediment that I presume to be pre-mining sediment has mercury concentrations with an order of magnitude of $10^{-2} \mathrm{ppm}$, which is of the same order of magnitude as the deposits found at the Blue Point Mine (Tables 1 and 2). The HMS has mercury concentrations with an order of magnitude of $10^{-1} \mathrm{ppm}$, which are ten times less than the sediment found at Rose Bar. The lower mercury levels in the HMS within the lower Yuba Fan relative to the Rose Bar sediment are most likely the result of downstream transport and mixing with uncontaminated sediment (Singer et al., 2013).

The sediment above and below the contact between the pre-mining sediment and the HMS predominantly consists of sandy HMS overlying relatively finegrained pre-mining sediment (Tables 1 and 2). The contact depth ranges from 1.32 to $7.53 \mathrm{~m}$. These depths compare favorably with the hypothesis of James et al. (2009) that the mean thickness of the HMS along the lower Yuba Fan is less than $7 \mathrm{~m}$. My results show that the thickness of the deposits decreases laterally away from the channel (Table B1 and Fig. 3). 
The pre-mining sediment within outcrops $\mathrm{OC} 2, \mathrm{OC} 3$, and OC5 contains layers of pre-mining sandy silt deposited on top of gravel (Table 2). The pre-mining gravel layer has a grain size distribution similar to that of the bed material of the present day channel, which is located at a lower elevation. From these observations, I concluded that the pre-mining gravel layer represents the bed material of the pre-mining channel prior to the channel laterally migrating to a different position and that the modern day Yuba River has incised farther than the pre-mining channel bed's elevation at these locations. Because the contacts between the HMS and pre-mining sediment had relatively fine-grained material surrounding them compared to the active channel's bed material, I inferred that the sampling sites were all above the pre-mining surface's floodplain and not within the confines of the pre-mining flowing channel.

From 1852 to 1911 , deposition occurred throughout most of the fan except in the northeast portion, where erosion occurred (Figs. 9 and 13). Accumulation of material was focused towards the center of the fan where the amount of deposition reached approximately $8.1 \mathrm{~m}$ (Fig. 9). Additionally, the volume of material increased by $9.19 \times 10^{7} \mathrm{~m}^{3}$ between 1852 and 1911 (Fig. 13 and Table 4). During this time period, the river had become braided with frequent avulsions due to the increased sediment supply (James et al., 2009). The large amount of deposition within the center of the fan may be the result of the pre-mining channel filling in with sediment as it migrated laterally. 
The comparison between the 1911 and 1952 DEM elevations shows that the lower Yuba Fan was mainly eroded during this time period (Figs. 9 and 13). The surface elevation decreased by up to $9.1 \mathrm{~m}$, and the volume decreased by $9.13 \times 10^{6} \mathrm{~m}^{3}$. The 1911 to 1952 choropleth map showing the zones of elevation change indicates that a large portion of the erosion occurred in the area where the present day channel is located. The high erosion rates near the current river position suggest that the main channel had begun to form (Figs. 9 -12) as the decrease in sediment supply induced higher vertical incision rates. Decreases in surface elevation also occurred along the present day floodplain between the Yuba River and the surrounding levees. Previous studies have shown that, around this time, high-water channels began to solidify their positions (James et al., 2009); therefore, the erosion on the floodplain could have been caused by sediment transport associated with the high-water channels.

From 1952 to 1999, the elevation of the surface of the lower Yuba Fan was decreased in some areas by up to $9.4 \mathrm{~m}$ and increased in other areas by up to $3.3 \mathrm{~m}$ (Fig. 9). Channel incision appears to be the main process that lead to the high amount of elevation decreases (Figs. 10 - 12). According to the difference map (Fig. 9), relatively low amounts deposition was dispersed throughout the floodplains and along the banks of the channel. The cut/fill analysis shows that $7.29 \times 10^{6}$ cubic meters of material was deposited within the confines of our study area (Fig. 13). By this time, the Yuba River had become stable at its current location and high-water channels became less numerous. Ghoshal et al. 
(2010) showed that the middle portion of lower Yuba Fan had net deposition within the channel and along the banks, which was attributed to the decennial flood events that significantly reworked the channel from 1952 to 2006.

The results of this study show that approximately $8.99 \times 10^{7} \mathrm{~m}^{3}$ of HMS were deposited within the study area between 1852 and 1999 (Fig. 13 and Table 4). Gilbert (1917) estimated that the hydraulic mines within the Yuba River watershed produced $5.23 \times 10^{8} \mathrm{~m}^{3}$ of HMS between 1849 and 1908. Therefore, approximately $17 \%$ of the HMS produced in mines along the Yuba River was deposited on the lower Yuba Fan. Gilbert's (1917) estimation of the volume of the Yuba Fan was $2.52 \times 10^{8} \mathrm{~m}^{3}$ of HMS. His estimate included the portion of the fan spanning from the Yuba Goldfields to the Narrows (Fig. 1), hence my estimate is lower since it focused on the lower portion of the fan.

The calculations performed in this study suggest that approximately $4.24 \times$ $10^{3} \mathrm{~kg}$ of mercury are within the HMS of the lower Yuba Fan. Churchill (1999) estimated that within all of the hydraulic gold mines in the Sierra Nevada from the mid 1800 s to the early $1900 \mathrm{~s}, 1.4 \times 10^{6}$ to $3.6 \times 10^{6} \mathrm{~kg}$ of mercury were lost to the environment. Therefore, my results suggest that $\sim 0.1-0.3 \%$ of the mercury lost to the environment when the hydraulic mines were active in the Sierra Nevada is stored within the lower Yuba Fan.

The calculation of the lower Yuba Fan's volume depended on the geometry of the pre-mining surface that I modeled. Further work is needed to more precisely recreate the pre-mining surface. Additional borings in the southernmost and 
northeastern portions of the fan would help improve the modeling of the premining surface's geometry. Because the southern levee was breached multiple times during flood events (James et al., 2009), collecting sediment samples outside of the levee corridor would provide further insight into the lateral extent of the HMS. 


\section{CONCLUSION}

The large quantity of HMS deposited along the floodplains of the southern portion of the Yuba River highlights the impacts of hydraulic mining operations within the region. Sediment samples were collected from various boreholes and outcrops along the lower Yuba Fan to quantify the amount of HMS accumulated in this area since the onset of hydraulic mining operations within the Yuba River watershed. This study revealed that the majority of the HMS was deposited between 1852 and 1911, causing a geomorphic shift from a single channel to a braided river system. The multi-channel Yuba River became vulnerable to flooding as the sediment load associated with the hydraulic mines became extreme. This time frame included the cessation of mining operations within the region. While the HMS supply to the river system may have decreased, the geomorphic transformations continued throughout the $20^{\text {th }}$ century. Between 1911 and 1952, the river began to erode the HMS and transition from a braided system back to a single channel. From 1952 to 1999 , the channel continued to incise into the alluvium, but floods resulted in an overall increase in material throughout the fan. Floodplain aggradation during this time left large quantities of contaminated sediment high above the present day Yuba River. As mercury-rich HMS from upstream sources such as Rose Bar continues to be deposited within the lower Yuba Fan, more contaminated sediment will become exposed to downstream ecosystems. 


\section{REFERENCES CITED}

Alpers, C.N., and Hunerlach, M.P., 2000, Mercury contamination from historic gold mining in California: U.S. Geological Survey Fact Sheet 061-00, 6 p.

Averill, C.V., 1946, Placer mining for gold in California: California State Division of Mines and Geology Bulletin 135, 377 p.

Bowie, A.J., 1893, A practical treatise on hydraulic mining in California: New York, Van Nostrand, $313 \mathrm{p}$.

Churchill, R., 1999, Insights into California mercury production and mercury availability for the gold mining industry from the historical record: Geological Society of America Abstracts with Programs, v. 31, p. 45.

Cox, P.A., 1989, The Elements: Their Origin, Abundance, and Distribution: Oxford, Oxford University Press, 207 p.

Donovan, P.M., Blum, J.D., Singer, M.B., Marvin-DiPasquale, M., Tsui, and M.T.K., 2016, Isotopic composition of inorganic and methylmercury downstream of historical gold mining: Environmental Science and Technology, v. 50, p. 1691-1702.

Environmental Systems Research Institute, 2013, ArcGIS: Release 10.2 [software]: Redlands California (CD-ROM).

Ghoshal, S., James, L. A., Singer, M. B., and Aalto, R., 2010, Channel and floodplain change analysis over a 100-year period: Lower Yuba River, California: Remote Sensing, v. 2, no. 7, p. 1797-1825.

Gilbert, G.K., 1917, Hydraulic-Mining Debris in the Sierra Nevada: U.S. Geological Survey Professional Paper 105, 154 p.

Gilmour, C.C., Podar, M., Bullock, A.L., Graham, A.M., Brown, S.D., Somenahally, A.C., Johs, A., Hurt, R.A, Jr., Bailey, K.L., and Elias, D.A., 2013, Mercury methylation by novel microorganisms from new environments: Environmental Science and Technology, v. 47, p. 1181011820.

Higson, J., and Singer, M., 2015, The impact of the streamflow hydrograph on sediment supply from terrace erosion: Geomorphology, v. 248, p. 475488. 
Hunerlach, M.P., Rytuba, J.J., and Alpers, C.N., 1999, Mercury contamination from hydraulic placer-gold mining in the Dutch Flat mining district, California, in Morganwalp, D.W., and Buxton, H.T., eds., U.S. Geological Survey Toxic Substances Hydrology Program - Proceedings of the Technical Meeting, Charleston, South Carolina, March 8-12, 1999: U.S. Geological Survey Water-Resources Investigations Report 99-4018B, v. 2, p. 179-189.

Hunerlach, M.P., Alpers, C.N., Marvin-DiPasquale, M., Taylor, H.E., and De Wild, J.F., 2004, Geochemistry of mercury and other trace elements in fluvial tailings upstream of Daguerre Point Dam, Yuba River, California, August 2001: U.S. Geological Survey Scientific Investigations Report 2004-5165, $66 \mathrm{p}$.

Hutchinson, M. F., 1989, A new procedure for gridding elevation and stream line data with automatic removal of spurious pits: Journal of Hydrology, v. 106, p. 211-232.

James, L. A., 1989, Sustained storage and transport of hydraulic gold mining sediment in the Bear River: California: Annals of the American Association of Geographers, v. 79, p. 570-592.

James, L. A., 1991, Incision and morphologic evolution of an alluvial channel recovering from hydraulic mining sediment: GSA Bulletin, v. 103, p. 723736.

James, L.A., 2005, Sediment from hydraulic mining detained by Englebright and small dams in the Yuba Basin: Geomorphology, v. 71, p. 202-226.

James, L.A., Singer, M.B., Ghoshal, S., and Megison, M., 2009, Historical channel changes in the lower Yuba and Feather Rivers, California: Longterm effects of contrasting river management strategies: Geological Society of America Special Paper, v.451, p. 57-81.

Kilham, N. E., Roberts, D., and Singer, M. B., 2012, Remote sensing of suspended sediment concentration during turbid flood conditions on the Feather River, California-A modeling approach: Water Resources Research, v. 48, p. W01521.

Lindgren, W., 1911, The Tertiary gravels of the Sierra Nevada of California: U.S. Geological Survey Professional Paper 73, 226 p.

Olund, S.D., DeWild, J.F., Olson, M.I., and Tate, M.T., 2005, Methods for the preparation and Analysis of Solids and Suspended Solids for Total 
Mercury, Book 5-Laboratory Analysis, Techniques and Methods: US Geological Survey, Reston, VA, 15 p.

Schlee, J., 1973, Atlantic continental shelf and slope of the United States -sediment texture of the northeastern part: U.S. Geological Survey Professional Paper 529-L, 64 p.

Shepard, F.P., 1954, Nomenclature based on sand-silt-clay ratios: Journal Sedimentary Petrology, v. 24, p. 151-158.

Singer, M.B., Aalto, R., James, L.A., Kilham, N.E., Higson, J.L., and Ghoshal, S., 2013, Enduring legacy of a toxic fan via episodic redistribution of California gold mining debris: Proceedings of the National Academy of Sciences, v. 110 , no. 46 , p. 18436-18441.

Singer, M.B., Harrison, L.R., Donovan, P.M., Blum, J.D., and Marvin-DiPasquale, M., 2016, Hydrologic indicators of hot spots and hot moments of mercury methylation potential along river corridors: Science of the Total Environment, v. 568, p. 697-711.

Soil Survey Staff, Natural Resources Conservation Service, United States Department of Agriculture. Web Soil Survey. Available online at http://websoilsurvey.nrcs.usda.gov/. Accessed (11/5/2016).

Stonestreet, S.E., and Lee, A.S., 2000, Use of LIDAR mapping for floodplain studies, in Building Partnerships, in Proceedings, 2000 Joint Conference on Water Resource Engineering, Planning, and Management: Minneapolis, MN, American Society of Civil Engineers.

U.S. Geological Survey, 1911, USGS 1:31680-scale Quadrangle for Yuba City, CA 1911: U.S. Geological Survey: Reston, VA, https://prdtnm.s3.amazonaws.com/StagedProducts/Maps/ HistoricalTopo/2/13241/4753174.pdf. Accessed (11/5/2016).

U.S. Geological Survey, 1952, USGS 1:24000-scale Quadrangle for Yuba City, CA 1952: U.S. Geological Survey: Reston, VA, https://prdtnm.s3.amazonaws.com/StagedProducts/ Maps/ HistoricalTopo/2/13260/4779554.pdf. Accessed (11/5/2016).

USDA-FSA-APFO Aerial Photography Field Office, 2014a, FSA 10:1 NAIP Imagery m_3912152_nw_10_1_20140725_201410073.75 x 3.75 minute JPEG2000 from The National Map: USDA-FSA-APFO Aerial Photography Field Office. 
USDA-FSA-APFO Aerial Photography Field Office, 2014b, FSA 10:1 NAIP Imagery m_3912152_ne_10_1_20140725_201410073.75 x 3.75 minute JPEG2000 from The National Map: USDA-FSA-APFO Aerial Photography Field Office.

USDA-FSA-APFO Aerial Photography Field Office, 2014c, FSA 10:1 NAIP Imagery m_3912153_nw_10_1_20140725_201410073.75 x 3.75 minute JPEG2000 from The National Map: USDA-FSA-APFO Aerial Photography Field Office.

USDA-FSA-APFO Aerial Photography Field Office, 2014d, FSA 10:1 NAIP Imagery m_3912152_sw_10_1_20140725_201410073.75 x 3.75 minute JPEG2000 from The National Map: USDA-FSA-APFO Aerial Photography Field Office.

USDA-FSA-APFO Aerial Photography Field Office, 2014e, FSA 10:1 NAIP Imagery m_3912152_se_10_1_20140725_201410073.75 x 3.75 minute JPEG2000 from The National Map: USDA-FSA-APFO Aerial Photography Field Office.

USDA-FSA-APFO Aerial Photography Field Office, 2014f, FSA 10:1 NAIP Imagery m_3912153_sw_10_1_20140725_201410073.75 x 3.75 minute JPEG2000 from The National Map: USDA-FSA-APFO Aerial Photography Field Office.

USDA-FSA-APFO Aerial Photography Field Office, 2014g, FSA 10:1 NAIP Imagery m_3912154_ne_10_1_20140713_201410073.75 x 3.75 minute JPEG2000 from The National Map: USDA-FSA-APFO Aerial Photography Field Office.

U.S. Geological Survey, 2013, USGS NED n40w122 1/3 arc-second 20131 x 1 degree ArcGrid: U.S. Geological Survey. 


\section{APPENDIX A. SAMPLING LOCATION INFORMATION}

Table A1. Borehole site specifications.

\begin{tabular}{lccccc}
\hline Boring ID & Latitude & Longitude & $\begin{array}{c}\text { Sampling } \\
\text { date }\end{array}$ & $\begin{array}{c}\text { Borehole } \\
\text { depth (m) }\end{array}$ & $\begin{array}{c}\text { No. of } \\
\text { samples }\end{array}$ \\
\hline B1 & $\mathrm{N} 39.135292^{\circ}$ & W $121.550865^{\circ}$ & $8 / 30 / 2014$ & 0.60 & 3 \\
B2 & $\mathrm{N} 39.135182^{\circ}$ & W $121.550820^{\circ}$ & $8 / 30 / 2014$ & 0.25 & 1 \\
B3 & $\mathrm{N} 39.135430^{\circ}$ & W $121.550870^{\circ}$ & $8 / 30 / 2014$ & 1.60 & 5 \\
B4 & $\mathrm{N} 39.129682^{\circ}$ & W $121.586592^{\circ}$ & $9 / 27 / 2014$ & 2.05 & 4 \\
B5 & $\mathrm{N} 39.131390^{\circ}$ & W $121.589260^{\circ}$ & $9 / 27 / 2014$ & 4.50 & 6 \\
B6 & $\mathrm{N} 39.177970^{\circ}$ & W $121.504908^{\circ}$ & $10 / 3 / 2014$ & 5.90 & 7 \\
B7 & $\mathrm{N} 39.170420^{\circ}$ & W $121.519690^{\circ}$ & $11 / 11 / 2014$ & 4.20 & 7 \\
B8 & $\mathrm{N} 39.161310^{\circ}$ & W $121.531270^{\circ}$ & $11 / 11 / 2014$ & 5.60 & 6 \\
B9 & $\mathrm{N} 39.170975^{\circ}$ & W $121.505685^{\circ}$ & $10 / 28 / 2015$ & 1.50 & 0 \\
B10 & $\mathrm{N} 39.161923^{\circ}$ & W $121.504874^{\circ}$ & $10 / 28 / 2015$ & 3.66 & 5 \\
B11 & $\mathrm{N} 39.182225^{\circ}$ & W $121.504719^{\circ}$ & $1 / 23 / 2016$ & 6.65 & 6 \\
B12 & $\mathrm{N} 39.159180^{\circ}$ & W $121.562589^{\circ}$ & $2 / 18 / 2016$ & 0.70 & 4
\end{tabular}

Table A2. Outcrop site specifications.

\begin{tabular}{|c|c|c|c|c|c|}
\hline Outcrop ID & Latitude & Longitude & $\begin{array}{c}\text { Sampling } \\
\text { date }\end{array}$ & $\begin{array}{c}\text { Column height } \\
(\mathrm{m})\end{array}$ & $\begin{array}{c}\text { No. of } \\
\text { samples }\end{array}$ \\
\hline OC1 & N $39.175852^{\circ}$ & W $121.524260^{\circ}$ & $3 / 23 / 2015$ & 7.89 & 4 \\
\hline OC2 & N $39.137209^{\circ}$ & W $121.580952^{\circ}$ & $8 / 3 / 2015$ & 6.55 & 6 \\
\hline OC3 & $N 39.164011^{\circ}$ & W $121.549936^{\circ}$ & 9/10/2015 & 8.75 & 6 \\
\hline OC4 & N $39.161184^{\circ}$ & W $121.554044^{\circ}$ & 9/10/2015 & 11.61 & 4 \\
\hline OC5 & N $39.159575^{\circ}$ & W $121.555336^{\circ}$ & 9/21/2015 & 7.16 & 3 \\
\hline OC6 & N $39.152415^{\circ}$ & W $121.565467^{\circ}$ & $9 / 21 / 2015$ & 9.51 & 5 \\
\hline
\end{tabular}

Table A3. Rose Bar and Blue Point Mine site specifications.

\begin{tabular}{|c|c|c|c|c|}
\hline Sample ID & Latitude & Longitude & Sampling date & No. of samples \\
\hline M1 & N $39.210040^{\circ}$ & W $121.284286^{\circ}$ & $3 / 26 / 2016$ & 1 \\
\hline M2S & N $39.208518^{\circ}$ & W $121.287418^{\circ}$ & $3 / 26 / 2016$ & 1 \\
\hline M2G & $N 39.208518^{\circ}$ & W $121.287418^{\circ}$ & $3 / 26 / 2016$ & 1 \\
\hline M3S & N $39.208221^{\circ}$ & W $121.288534^{\circ}$ & $3 / 26 / 2016$ & 1 \\
\hline M3G & N $39.208221^{\circ}$ & W $121.288534^{\circ}$ & $3 / 26 / 2016$ & 1 \\
\hline M4 & N $39.208383^{\circ}$ & W $121.288086^{\circ}$ & $3 / 26 / 2016$ & 1 \\
\hline R1 & N $39.221628^{\circ}$ & W 121.295052 & $3 / 26 / 2016$ & 1 \\
\hline R2 & N $39.219838^{\circ}$ & W 121.297407 & $3 / 26 / 2016$ & 1 \\
\hline R3 & N $39.218747^{\circ}$ & W 121.298676 & $3 / 26 / 2016$ & 1 \\
\hline R4 & N $39.217789^{\circ}$ & W $121.297185^{\circ}$ & $3 / 26 / 2016$ & 1 \\
\hline R4N & N $39.217789^{\circ}$ & W $121.297185^{\circ}$ & $3 / 26 / 2016$ & 1 \\
\hline R5 & N $39.218498^{\circ}$ & W 121.297839 & $3 / 26 / 2016$ & 1 \\
\hline R6 & N $39.218983^{\circ}$ & W 121.299183 & $3 / 26 / 2016$ & 1 \\
\hline
\end{tabular}




\section{APPENDIX B. GEOGRAPHIC INFORMATION SYSTEMS SPATIAL DATA}

Table B1. Contact elevation data for boring and outcrop samples.

\begin{tabular}{lccc}
\hline $\begin{array}{l}\text { Sample } \\
\text { name }\end{array}$ & Contact depth $(\mathbf{m})$ & $\begin{array}{c}\text { Surface elevation } \\
\text { (m above mean sea level) }\end{array}$ & $\begin{array}{c}\text { Contact elevation } \\
\text { (m above mean sea level) }\end{array}$ \\
\hline B1 & Not found & 21.23 & Not found \\
B2 & Not found & 21.28 & Not found \\
B3 & 1.32 & 21.42 & 20.10 \\
B4 & 1.85 & 14.25 & 12.40 \\
B5 & Not found & 19.59 & Not found \\
B6 & Not found & 28.42 & Not found \\
B7 & 2.80 & 25.04 & 22.24 \\
B8 & Not found & 25.38 & Not found \\
B10 & 3.14 & 26.14 & 23.00 \\
B11 & 5.45 & 28.89 & 23.44 \\
B12 & Not found & 22.49 & Not found \\
OC1 & 7.00 & 26.65 & 19.65 \\
OC2 & 4.02 & 20.05 & 16.03 \\
OC3 & 7.53 & 23.90 & 16.37 \\
OC4 & 6.81 & 23.68 & 16.87 \\
OC5 & Not found & 18.14 & Not found \\
OC6 & 5.63 & 21.60 & 15.97
\end{tabular}

Table B2. Contact elevation estimations for field sites where the contact between the pre-mining sediment and HMS was not encountered.

\begin{tabular}{lccc}
\hline $\begin{array}{l}\text { Sample } \\
\text { name }\end{array}$ & Contact depth $(\mathbf{m})$ & $\begin{array}{c}\text { Surface elevation } \\
\text { (m above mean sea level) }\end{array}$ & $\begin{array}{c}\text { Contact elevation } \\
\text { (m above mean sea level) }\end{array}$ \\
\hline B5 & $\sim 5.00$ & 19.59 & 14.59 \\
B6 & $\sim 6.40$ & 28.42 & 22.02 \\
B8 & $\sim 6.10$ & 25.38 & 19.28 \\
B12 & $\sim 1.20$ & 22.49 & 21.29 \\
OC5 & $\sim 1.72$ & 18.14 & 16.42
\end{tabular}

